\title{
6 The Second Level of the Aspectuality Model Applied
}

\subsection{Introductory remarks}

This chapter deals with the second level of perspectivisation of the model of aspectuality within situation frames, a level that is created through further recursive perspectivisation (or focussing) of some of the outcomes of the first level of perspectivisation.

In the first part of Chapter 6 I will - as previously in Chapter 5 - give an exact, but in this case not fully comprehensive, description of the possible and impossible combinations of basic conceptualisations on the second level. In the Romance languages, it is mainly constructions such as verbal periphrases that are used to express those complex structurings of aspectuality which the model conceives as a second level of perspectivisation within situation frames. However, this second level is not expressed exclusively by verbal periphrases (it has been stressed several times that languages have several means to express the same aspectual content), nor can all aspectual verbal periphrases be regarded exclusively as realisations of this second level of perspectivisation. In the previous chapter some of these constructions were analysed as the expression of combinations of the three perspectives of aspectuality on the first level (see, among others, example (19) in §5.2.2.5 or (21) and (22) in §5.2.2.6). However, the possibility cannot be excluded that there are languages that express this second level of perspectivisation only through purely lexical (e.g., adverbs) or purely morphological forms (e.g., synthetic verb markers) and in which verbal periphrases either do not occur or they play an insignificant role. ${ }^{1}$

In the second part of the chapter, I examine in more detail the phenomenon of periphrastic verbal constructions, which are very important in the Romance languages and almost a classic issue in Romance linguistics. The theoretical leitmotif of the second part of the chapter is a general discussion of the problem of what the underlying factor is that unites all aspectual verbal periphrases and to which aspectual categories - semantically separate in the bidimensional conception they are to be assigned, in other words, the question of whether aspectual verbal periphrases are to be considered aspect or Aktionsart. On the basis of the theoretical approach to aspectuality presented here, a new analysis of the phenomenon is

1 This is the case in Russian, for example, where verbal periphrases play a more peripheral role and are not grammaticalised, apart from the formation of the future with budu.

¿ Open Access. (C) 2019 Sarah Dessì Schmid, published by De Gruyter. (cc) BY-NC-ND This work is licensed under a Creative Commons Attribution-NonCommercial-NoDerivatives 4.0 International License. 
undertaken that strongly relativises the relevance of this question, which is difficult to answer with the traditional semasiological approach.

\subsection{Aspectual delimitation schemas of the second level of the model}

\subsubsection{An inventory of the delimitation schemas of the second level}

In Chapter 5 (see §5.2.1) an inventory of all the possible and impossible combinations of the aspectual basic conceptualisations was presented and illustrated graphically with delimitation schemas. However, only the first level of aspectual delimitation was presented, and the inventory did not include further perspectivisations - such as those that emerge, for example, from the analysis of states of affairs with more complex temporal structures, as they are examined in more detail in this chapter. On the following pages, the individual delimitation schemas of this second level of the model are presented.

First, however, I must explain what exactly is meant by the second level of perspectivisation. Aspectuality has been defined as internal temporal structuring, as the temporal-structuring delimitation of a state of affairs conceived as a situation frame, while the relations between the elements of this frame and between the frame as a whole and its constitutive elements have been defined as relations of contiguity (see $§ 3.2 .3$ on the association principle of contiguity in general). In this context, "temporal-structuring delimitation" has been understood in very general terms as "determination" or "boundary setting”, which - as an internally temporal constituting act of a state of affairs - necessarily emphasises or focusses on some temporal realities over others, which in turn recede into the background (see §4.2).

These focussing operations are recursive, repeatable within the frame, and can therefore occur on several levels. In a state of affairs in which aspectual basic conceptualisations of the following type [externally non-delimited (EA/nd) + not relevant to adjacency (AA/nr) + internally subdivided (IA/s)] are combined - and this represents the first level of focussing within the situation frame - a moment $t_{x}$ or several of the constitutive moments $t_{x 1}, t_{x 2}, \ldots t_{x n}$ of the state of affairs can, for their part, be focussed, and in relation to this/these new boundary setting(s) the three perspectives of aspectuality are newly conceived.

Figures (1) and (2) illustrate this. For practical reasons, the images in both figures summarise the three perspectives of aspectuality (while in §§6.2.2.1-6.2.2.12 all basic conceptualisations are illustrated individually using examples). Figure (1) shows how a single moment $t_{x}$ of the first level of the state of affairs (highlighted 
with an outline) is further focussed on the second level, while Figure (2) represents the further focussing of several moments on the second level:

1st level: DS $2[(E A / n d)+(A A / n r)+(I A / s)]$

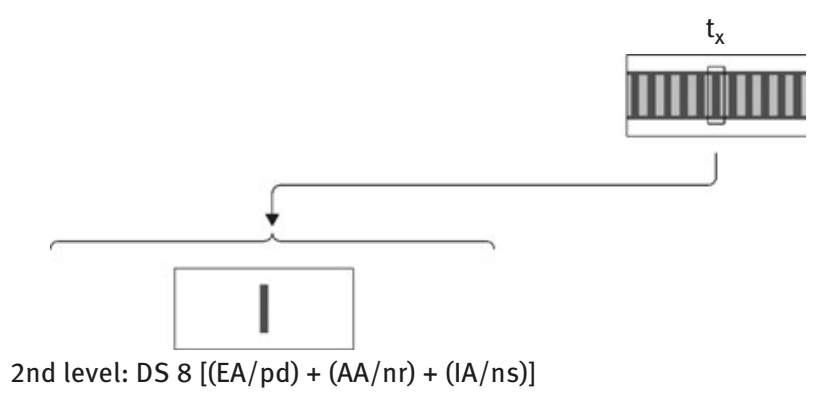

Fig. 1: Second level of focussing, a first example.

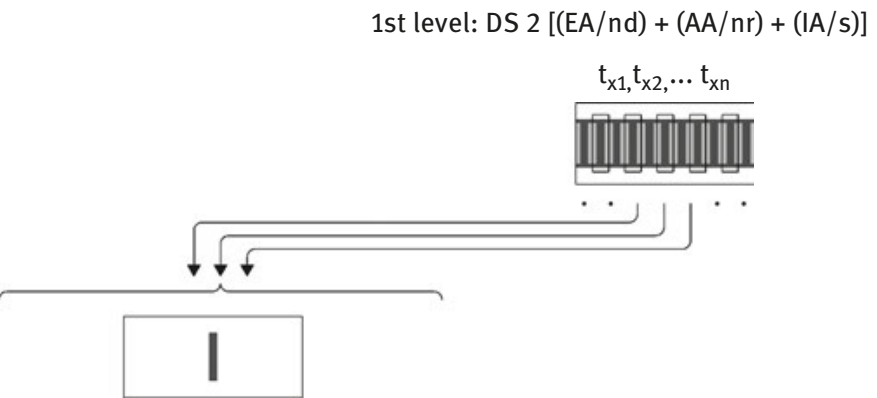

2nd level: $D S$ 8, 8, 8, .. [((EA/pd) + (AA/nr) + (IA/ns)) + ((EA/pd) + (AA/nr) + (IA/ns)) $+((E A / p d)+(A A / n r)+(I A / n s))+\ldots]$

Fig. 2: Second level of focussing, a second example.

These perspectivisations on several levels within the situation frame represent complex temporal structurings of states of affairs, such as the so-called "progressive" aspectual structurings, which need to be analysed in more detail here.

The inventory of second-level aspectual delimitation schemas is thus based on those of the first level, although, logically, only those with pluriphasic situation frames, in other words, those with an internal aspectuality of the type "subdivided" (IA/s), because it is only here that further focussing is possible. Only where different moments $t_{x 1}, t_{x 2}, \ldots t_{x n}$ are perceptible, can they be (individually or severally) further highlighted within the situation frame. 
Table (1) presents those first-level delimitation schemas that are open to further perspectivisation: these were labelled in §5.2.1 as delimitation schemas (DS) 2, 4, 5, 6 and 7. This numbering is also used to denote the combination of delimitation schemas on the two perspectivisation levels - separated by a slash - according to the pattern DS $\mathrm{x} / \mathrm{y}$, where $\mathrm{x}$ represents the delimitation schema of the first level, $\mathrm{y}$ that of the second.

Tab. 1: Inventory of the further perspectivisable delimitation schemas.

\begin{tabular}{|c|c|c|c|}
\hline $\begin{array}{l}\text { External } \\
\text { Aspectuality } \\
\text { (EA) }\end{array}$ & $\begin{array}{l}\text { Adjacency- } \\
\text { related } \\
\text { Aspectuality (AA) }\end{array}$ & $\begin{array}{l}\text { Internal } \\
\text { Aspectuality } \\
\text { (IA) }\end{array}$ & $\begin{array}{l}\text { Delimitation } \\
\text { Schemas (DS) }\end{array}$ \\
\hline $\mathrm{EA} / \mathrm{nd}$ & $\mathrm{AA} / \mathrm{nr}$ & $\mathrm{IA} / \mathrm{s}$ & DS 2 \\
\hline$E A / d$ & $\mathrm{AA} / \mathrm{nr}$ & $\mathrm{IA} / \mathrm{s}$ & DS 4 \\
\hline $\mathrm{EA} / \mathrm{d}$ & $\mathrm{AA} / \mathrm{fr}$ & $\mathrm{IA} / \mathrm{s}$ & DS 5 \\
\hline $\mathrm{EA} / \mathrm{d}$ & $\mathrm{AA} / \mathrm{ir}$ & $\mathrm{IA} / \mathrm{s}$ & DS 6 \\
\hline$E A / d$ & $\mathrm{AA} / \mathrm{tr}$ & $\mathrm{IA} / \mathrm{s}$ & DS 7 \\
\hline
\end{tabular}

In the Romance languages dealt with here, delimitation schemas 2, 4, 5, 6 and 7 are not all equally relevant for the second level of aspectuality, i.e., not all the possible combinations of these DSs are actually realised. They are also not formally realised in the same way in all Romance languages, because, for example, only in Spanish and Catalan can certain aspectual DSs be expressed by verbal periphrases.

In the following paragraphs (§§6.2.2.1-6.2.2.12) I will present the various possibilities of further perspectivisation individually and analyse them in more detail. However, a complete inventory is not provided here, as it was in Chapter 5, for in such a - non-typologically-oriented - classification, there would be too many 
omissions in the various (only partially given) representations of the Romance languages analysed here (which also reflect their various preferences). It is therefore more economical to focus the analysis on the most important and most frequent cases in which aspectuality is expressed on the second level of the model.

This does not imply that it is not possible for other languages to make use of all possible combinations exhaustively, nor that the model presented here is weakened by this, because the complete inventory with the systematisation given here would always be available for any languages that require it.

As in the previous chapters (\$§4.4.3ff. and §§5.2.2ff.), examples from the four Romance languages dealt with are commented on in parallel as far as possible. In these, the content category aspectuality is expressed by different means - lexical and grammatical - and they mostly have different tenses. $^{2}$

\subsubsection{Presentation of the individual delimitation schemas}

\subsubsection{Delimitation Schema 2/8: $[((E A / n d)+(A A / n r)+(I A / s))>((E A / p d)+$} $(\mathrm{AA} / \mathrm{nr})+(\mathrm{IA} / \mathrm{ns}))]$

(1) It. La gatta di Leo sta [Pres.] dormendo profondamente. [stare + Ger.] 'Leo's cat is sleeping deeply.'

(2) Fr. Daniela était [Imp.] en train de parler avec Julien. [être en train de + Inf.] 'Daniela was speaking with Julien.'

(3) Sp. ¡Mira! Juan duerme [Pres.] con un ojo abierto. ${ }^{3}$

'Look! Juan is sleeping with one eye open.'

2 Here, too, information on temporal markings of a deictic nature is given in square brackets within the examples themselves; special periphrastic constructions are noted in square brackets after the examples.

3 Duerme/dormía con un ojo abierto can have two aspectual meanings (see also §5.2.2.2, Delimitation Schema 2: [EA/nd) + (AA/nr) + (IA/s)]) and these are made more or less explicit by the context. The first (shown in Chapter 5) is a temporally absolute meaning (he always sleeps/slept with one eye open); in contrast, the second (the one in question here) expresses the closer observation of a special moment $t_{x}$ of Juan's sleeping. This moment is highlighted within the situation frame, which is already temporally structured on the first level, and further aspectual coordinates of this $t_{x}$ can be determined (i.e., which combination of aspectual basic conceptualisations is represented in relation to this focussed moment). 
(4) Cat. La Rosina estava [Imp.] menjant tranquil·lament. ${ }^{4}$ [estar + Ger.] 'Rosina was eating calmly.'

The states of affairs represented in examples (1)-(4) show a combination of aspectual basic conceptualisations of the following type: ${ }^{5}$

First level:

a) externally non-delimited (EA/nd)

b) not relevant to adjacency $(\mathrm{AA} / \mathrm{nr})$

c) internally subdivided (IA/s)

Second level:

a') externally punctually delimited (EA/pd)

b') not relevant to adjacency $(\mathrm{AA} / \mathrm{nr})$

c') not internally subdivided (IA/ns)

In (1)-(4), on the first level of the combination of aspectual basic conceptualisations, a) neither a starting point $t_{x}$ nor an endpoint $t_{y}$ of the respective entire states of affairs is focussed - i.e., neither the beginning nor the end of the deep sleeping of Leo's cat in (1), of Daniela speaking with Julien in (2), of Juan sleeping with one open eye in (3), or of Rosina's eating in (4). In other words, the state of affairs in question is not presented as a whole and therefore not as completed. Therefore, $b$ ) it is also logically impossible to find any relevance for its adjacency, because there is no initial boundary $t_{x}$ and no final boundary $t_{y}$ of the respective states of affairs, which would allow the constitution of their adjacencies. Finally, c) (substantially) different moments $t_{x 1}, t_{x 2}, \ldots t_{x n}$ can be found in the pluriphasic state of affairs: Leo's cat slept through all these

4 A sentence like La Rosina estava menjant tranquil-la una galeta would have exactly the same delimitation schema. To show once again how the interaction of different elements in the frame leads to different delimitation schemas, it can be compared with the sentence $L a$ Rosina estava menjant tranquil.la galetes, which has a DS $2 / 8,8,8, \ldots$ as in $\S 6.2 .2 .5$. The presence of galetes here in the plural (and without further indicators of definiteness, such as the definite article) influences this reading: the speaker knows from his/her world knowledge that eating several biscuits is an iterated process with a duration, and therefore expresses the state of affairs in this way.

5 The aspectual structuring of states of affairs of this type corresponds to what in traditional studies has been termed "progressive-focalised" (see, among others, Bertinetto 1995a and $\S 6.3 .3$ here). 
moments $t_{x 1}, t_{x 2}, \ldots t_{x n}$ and each of these moments can be viewed and represented individually and in isolation - in each $t_{x 1}$ Leo's cat slept differently (deeper, more lightly, etc.) than in $t_{x 2}$ (likewise, in each $t_{x 1}$ Daniela spoke to Julien further and slightly differently than in $t_{x 2}$, Juan slept differently with one open eye and Rosina ate more or less calmly).

It is exactly this aspect that is the prerequisite for further perspectivisation within the situation frame, for only if it is possible, as is the case here, to set further subdivision points or boundaries in the temporal structuring of the state of affairs, i.e., to set discrete temporal subintervals $t_{x 1}, t_{x 2}, \ldots t_{x n}$, is it also possible to further focus one or more of these subintervals (this was already emphasised above), around which subframes emerge. In (1)-(4) a special $t_{x 1}$ is focussed in each case (a single moment in the sleeping of Leo's cat, in Daniela's speaking with Julien, etc.) and this represents a subframe within the whole frame. The respective subframes in turn represent the following combination of aspectual basic conceptualisations: they are a') externally punctually delimited $(\mathrm{EA} / \mathrm{pd})$ : the beginning and the end of the moment $\mathrm{t}_{\mathrm{x} 1}$ in the sleeping of Leo's cat are evidently focussed, out of which this sleeping is presented, and the beginning and the end coincide (thus it is a $\delta t_{x 1}$ ). In addition, these subframes b') in the states of affairs are not relevant for their adjacencies (AA/nr): the sleeping of Leo's cat and Daniela's speaking with Julien, etc., do not influence their adjacencies, because they determine neither the beginning nor the end of a new state of affairs, nor the beginning or the end of the states of affairs themselves (the sleeping or speaking). Finally, the respective subframes c') are not internally subdivided (IA/ns), as is logically the case with states of affairs of the type EA/pd.

This is formally represented by the strongly grammaticalised periphrastic constructions of the type STARE + gerund in (1) and (4), by être en train de + infinitive in (2) and by the present tense in (3) (supported by further elements such as imira!, which excludes a generic reading here), in combination with the verbs 'to sleep', 'to speak' and 'to eat' and their respective first arguments (la gatta di Leo, Daniela, Juan and Rosina). This type of combination of aspectual basic conceptualisations can be illustrated as in Table (2): 
Tab. 2: $D S$ 2/8: $[((E A / n d)+(A A / n r)+(I A / s))>((E A / p d)+(A A / n r)+(I A / n s))]$.

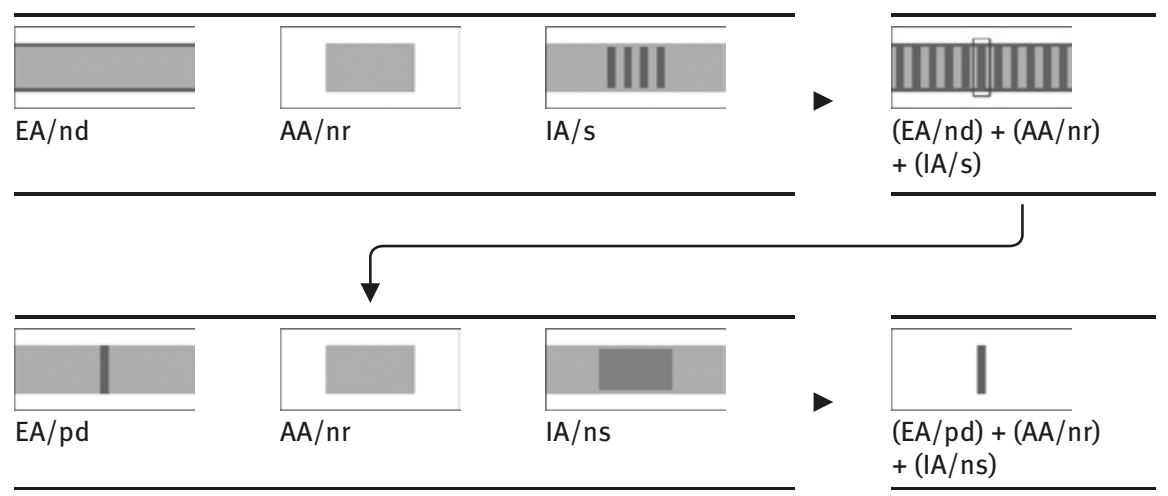

6.2.2.2 Delimitation Schema 2/9: $[((E A / n d)+(A A / n r)+(I A / s))>((E A / p d)+$ $(\mathrm{AA} / \mathrm{fr})+(\mathrm{IA} / \mathrm{ns}))]$

(5) It. Leo sta [Pres.] tornando a casa dal primo giorno di scuola. [stare + Ger.] 'Leo is coming home from his first day at school.'

(6) Fr. Julie est [Prés.] en train de terminer sa thèse de doctorat. [être en train de + Inf.]

'Julie is (currently) finishing her doctoral thesis.'

(7) Sp. Juan regresaba [Imp.] a su país, cuando lo encontré en el tren. 'Juan was returning to his country, when I met him on the train.'

(8) Cat. El dia estava [Imp.] morint lentament. [estar + Ger.] 'The day was slowly dying.'

The states of affairs represented in examples (5)-(8) have the following combination of aspectual basic conceptualisations:

First level:

a) externally non-delimited (EA/nd)

b) not relevant to adjacency (AA/nr)

c) internally subdivided (IA/s) 


\section{Second level:}

a') externally punctually delimited (EA/pd)

b') with final adjacency relevance (AA/fr)

c') not internally subdivided (IA/ns)

In (5)-(8), on the first level of the combination of aspectual basic conceptualisations, a) neither a starting point $t_{x}$ nor an endpoint $t_{y}$ of the respective entire states of affairs is focussed - i.e., neither the beginning nor the end of Leo's coming home in (5), of Julie's finishing her doctoral thesis in (6), of Juan's returning in (7) or of the slow dying of the day in (8) -, so that the respective states of affairs are presented as not completed. Therefore, b) these states of affairs are irrelevant for their adjacencies (since there are no initial and final boundaries $t_{x}$ and $t_{y}$ of the states of affairs themselves, which would allow the constitution of their adjacencies). Finally, c) substantially different moments $t_{x 1}, t_{x 2}, \ldots t_{x n}$ can be found here, i.e., it is possible to identify discrete temporal subintervals in Leo's coming home (in each of which he comes home), in Julie's finishing her work, in Juan's returning and in the slow dying of the day.

The realisation of internal aspectuality within the situation frame is the prerequisite for further perspectivisation: of the various $t_{x 1}, t_{x 2}, \ldots t_{x n}$ in Leo's coming home in (5) a particular $t_{\mathrm{x} 1}$ is further focussed (as well as a single moment in Julie's finishing her work in (6), in Juan's returning in (7) and in the slow dying of the day in (8)). This $t_{x 1}$ represents a temporal boundary around which a subframe is formed within the entire frame, which expresses the following combination of aspectual basic conceptualisations: the subframes are a') externally punctually delimited (EA/pd): the focus is on the beginning and the end of the moment $t_{x 1}$ in Leo's coming home, from the perspective of which this coming home is represented, and these moments coincide (thus it is a $\delta t_{x 1}$ ). The subframes have b') final adjacency relevance (AA/fr): the $t_{x 1}$ in Leo's coming home, which is focussed (as is the $t_{x 1}$ in Julie finishing her work or in the slow dying of the day), influences its previous adjacency (here $t_{x 1-1}$, the moment before that which is focussed) by determining its end (the end of the previous adjacency of the subframe, that is, not that of the whole state of affairs). In the focussed $t_{x 1}$, Leo is closer to his final coming home than in $t_{x 1-1}$. It is precisely this realisation of the adjacency reference that denotes the dynamicity within the situation frame. Finally, the subframes c') are not internally subdivided (IA/ $\mathrm{ns),} \mathrm{as} \mathrm{is} \mathrm{logical} \mathrm{for} \mathrm{states} \mathrm{of} \mathrm{affairs} \mathrm{with} \mathrm{EA/pd.}$

The aspectual content described here is conveyed by verbal periphrases of the type STARE + gerund in (5) and (8) (with the auxiliary verb in the present tense and the imperfect, respectively) and the type être en train de + infinitive in (6) (with the auxiliary verb in the present tense), and by the imperfect in (7) 
in combination with the verbs 'to come home', 'to finish the dissertation', 'to return' and 'to die' (and their respective first and, in part, further arguments). This type of delimitation schema (2/9) can be illustrated as in Table (3):

Tab. 3: $D S 2 / 9[((E A / n d)+(A A / n r)+(I A / s))>((E A / p d)+(A A / f r)+(I A / n s))]$.

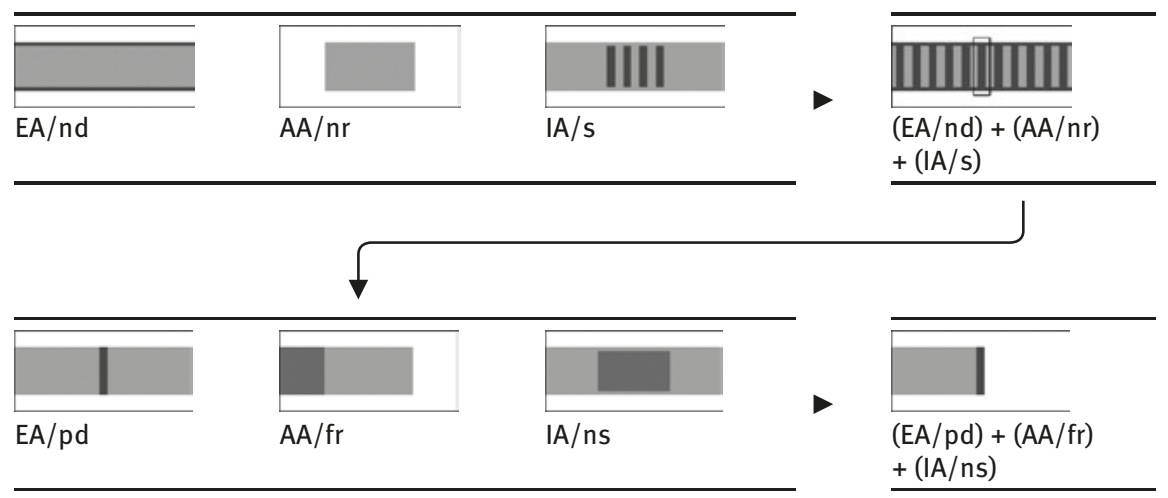

6.2.2.3 Delimitation Schema 2/10: $[((E A / n d)+(A A / n r)+(I A / s))>((E A / p d)+$ $(A A / i r)+(I A / n s))]$

(9) It. Leo sta [Pres.] partendo per l'Italia. [stare + Ger.]

'Leo is leaving for Italy.'

(10) Fr. Elle était $[\mathrm{Imp}$.$] en train de quitter son bureau. [être en train de + Inf.]$ 'She was leaving her office.'

(11) Sp. Juan salía [Imp.] para Córdoba, cuando lo encontré en la estación. 'Juan was leaving for Cordoba, when I met him at the station.'

(12) Cat. La lluna estava [Imp.] sortint. [estar + Ger.] 'The moon was rising.'

The states of affairs in examples (9)-(12) represent a combination of aspectual basic conceptualisations of the following type: 
First level:

a) externally non-delimited (EA/nd)

b) not relevant to adjacency $(\mathrm{AA} / \mathrm{nr})$

c) internally subdivided (IA/s)

Second level:

a') externally punctually delimited (EA/pd)

b') with initial adjacency relevance (AA/ir)

c') not internally subdivided (IA/ns)

In (9)-(12), on the first level of the combination of aspectual basic conceptualisations, a) neither a starting point $t_{x}$ nor an endpoint $t_{y}$ of the respective entire states of affairs is focussed - i.e., neither the beginning nor the end of Leo's and Juan's departure in (9) and (11), the leaving of the office in (10) or the rising of the moon in (12) -, so that the respective states of affairs are represented as not completed. Therefore, b) this type of state of affairs is irrelevant for its adjacency. Finally, c) different moments $t_{x 1}, t_{x 2}, \ldots t_{x n}$, specific temporal subintervals, in Leo's and Juan's departure in (9) and in (11), the leaving of the office in (10) and the rising of the moon in (12) can be identified.

The realisation of internal aspectuality within the situation frame is - and this has been clarified several times - the prerequisite for further perspectivisation. Of the various $t_{x 1}, t_{x 2}, \ldots t_{x n}$ in Leo's and Juan's departure in (9) and (11), a particular $t_{x 1}$ is focussed, as is a single moment in the leaving of the office in (10) and in the rising of the moon in (12). This $t_{x 1}$ represents a temporal boundary around which a subframe is formed within the entire frame.

The combination of aspectual basic conceptualisations is expressed as follows: the respective subframes are a') externally punctually delimited (EA/pd): the beginning and the end of the moment $t_{x 1}$ in Leo's departure, out of which this departure itself is presented, are focussed, and these boundaries coincide.

The respective subframes have b') initial adjacency relevance (AA/ir): the $t_{x 1}$ in Leo's and Juan's departure that is focussed (as is the $t_{x 1}$ in Julie's leaving her office, etc.), influences its subsequent adjacency (here $t_{x 1+1}$, i.e., the moment after the focussed one) by determining its beginning (the beginning of the subsequent adjacency of the subframe, that is, not of the whole state of affairs). In the focussed $t_{x 1}$ Leo is closer to his departure from home than in $t_{x 1+1}$. The dynamicity in the situation frame is represented precisely by this realisation of the adjacency reference.

Finally, the respective subframes c') are not internally subdivided (IA/ns), as is logical for states of affairs with EA/pd. The aspectual contents described are conveyed as follows: by verbal periphrases of the type STARE + gerund in (9) 
and (12) (with the auxiliary verb in the present tense and the imperfect, respectively) or the type être en train de + infinitive in (10) (with the auxiliary verb in the imperfect), or by the imperfect in (11) in combination with the verbs 'to leave for Italy (or Cordoba)', 'to leave the office', and 'to rise' (and their respective first and, in part, further arguments). The role of the subordinate clause cuando lo encontré en la estación in (11) seems to be particularly important in order to disambiguate the interpretation of the entire situation frame: the moment of the meeting at the station is also the precise moment of the main clause Juan salía para Córdoba that is highlighted and further focussed.

Table (4) illustrates this combination of basic conceptualisations (DS 2/10):

Tab. 4: DS 2/10: $[((E A / n d)+(A A / n r)+(I A / s))>((E A / p d)+(A A / i r)+(I A / n s))]$.

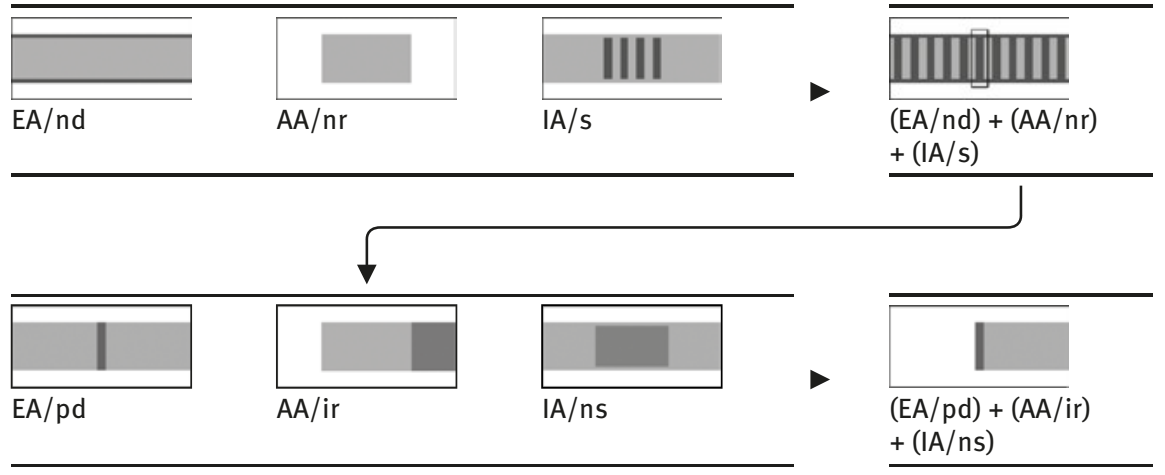

\subsubsection{Delimitation Schema 2/11: $[((E A / n d)+(A A / n r)+(I A / s))>((E A / p d)+$ $(\mathrm{AA} / \mathrm{tr})+(\mathrm{IA} / \mathrm{ns}))]$}

(13) It. Guarda: il fuoco d'artificio sta [Pres.] esplodendo nel cielo! [stare + Ger.] 'Look: the firework is exploding in the sky!'

(14) Fr. La guerre éclatait [Imp.] de partout, quand il naquit.

'War was breaking out everywhere, when he was born.'

(15) Sp. La bailarina estaba [Imp.] enrojeciendo de repente por culpa de su maestra, cuando la vi la primera vez. [estar + Ger.]

'The dancer was suddenly blushing because of her teacher, when I saw her for the first time.' 
(16) Cat. Vaig conèixer en Xavier en el moment que s'enamorava [Imp.] perdudament del mar.

'I met Xavier at the moment he was falling hopelessly in love with the sea.'

The states of affairs in examples (13)-(16) represent a combination of aspectual basic conceptualisations of the following type:

First level:

a) externally non-delimited (EA/nd)

b) not relevant to adjacency $(\mathrm{AA} / \mathrm{nr})$

c) internally subdivided (IA/s)

Second level:

a') externally punctually delimited (EA/pd)

b') with initial and final (transformative) adjacency relevance (AA/tr)

c') not internally subdivided (IA/ns)

Before analysing the above cases, I will discuss an objection that could be raised against examples (13) and (14) from the perspective of the traditional bidimensional interpretation of aspectuality. In §5.2.2.11 (Delimitation Schema 11), example (41) (It. Il palloncino esplose improvvisamente provocando il pianto dei bambini) was presented as an expression of a type of state of affairs with the following combination of aspectual basic conceptualisations: [(EA/pd) + (AA/tr) + (IA/ns)]. Now, how can a state of affairs expressing external aspectuality of the type punctual be further perspectivised, when it is only where $t_{x 1}, t_{x 2}, \ldots t_{x n}$ are perceptible that one or several of them can be highlighted within the situation frame? The reason is simple: that a state of affairs represents a special combination of aspectual basic conceptualisations is related to the convergence, the interaction or interdependence of different elements in this situation frame. It does not depend exclusively - as is assumed from the perspective of verb classification, which also separates aspect (markings) and Aktionsart - on the semantic (lexical) meaning of an aspectual nature (which is called Aktionsart) of the verb itself, independent of the context of use. The polysemous verb esplodere expresses external aspectuality of the type punctual only if it occurs in combination with elements such as those in (41), DS 11, §5.2.2.11. But when it appears in a situation frame like that in (13), it takes on another of its possible meanings and a different delimitation schema. This requires more detailed analysis.

In (13)-(16), on the first level of the combination of aspectual basic conceptualisations, a) neither a starting point $t_{x}$ nor an endpoint $t_{y}$ of the respective 
entire states of affairs is focussed - i.e., neither the beginning nor the end of the exploding of the firework in (13), the breaking out of war in (14), the blushing of the dancer in (15) or the falling in love of Xavier in (16) -, so that the respective states of affairs are represented as not completed. This type of state of affairs is therefore b) irrelevant to its adjacency. Finally, c) different, consecutive $t_{x 1}, t_{x 2}, \ldots t_{x n}$, discrete temporal subintervals, can be perceived in the exploding of the firework in (13) (as well as in the breaking out of war, the blushing of the dancer or the falling in love of Xavier), because the 'exploding of a firework' is also anchored in the speaker's world knowledge with a certain duration, as is the breaking out of war with its temporal graduality.

It is precisely this realisation of internal aspectuality (IA/s) that constitutes the prerequisite for further perspectivisation within the situation frame. Of the different $t_{x 1}, t_{x 2}, \ldots t_{x n}$ in the exploding of the firework (and in the breaking out of war, etc.) a special $t_{x 1}$ is further focussed, so that we could speak of a "zoom effect". Around this $t_{x 1}$, a subframe is formed with the following combination of aspectual basic conceptualisations: the subframe is a') externally punctually delimited (EA/pd): the beginning and the end of the moment $t_{x 1}$ in the exploding of the firework, from which this exploding itself is depicted, are prominently in focus and these boundaries coincide. The subframe has b') transformative adjacency relevance (AA/tr): the $t_{x 1}$ in the exploding of the firework (and in the breaking out of war, the blushing of the dancer or the falling in love of Xavier), which is focussed, influences its previous and subsequent adjacencies (these are labelled $t_{x 1-1}$ and $t_{x 1+1}$, respectively, the moment before and the moment after the focussed $t_{x 1}$ ) by determining, respectively, their end and their beginning. The focussed $t_{x 1}$ in (13) is a moment in an explosion of a firework which does not yet exist in $t_{x 1-1}$ and no longer exists in $t_{x 1+1}$. Finally, the respective subframes c') are not internally subdivided (IA/ns), since they are subframes with EA/pd. The aspectual contents described are conveyed by the following different forms: verbal periphrases of the type STARE + gerund in (13) and (15) (with the auxiliary verb in the present tense and imperfect, respectively), and by the imperfect in (14) and (16) in combination with the verbs 'to explode', 'to break out', 'to blush' and 'to fall in love' (and their first and, in part, further arguments) and with the connectors quand and cuando. The role of the elements guarda in (13), quand il naquit in (14), cuando la vi la primera vez in (15) and en el moment que s'enamorava del mar in (16) is also very important, as they disambiguate the interpretation of the entire situation frame: the moment in which the speaker demands the attention of the hearer by means of guarda, the moment of the birth, of the first encounter and the moment in which he 
fell in love with the sea, represent a precise moment, highlighted within the main clause, which is further focussed.

Table (5) illustrates this delimitation schema (2/11):

Tab. 5: $D S$ 2/11: $[((E A / n d)+(A A / n r)+(I A / s))>((E A / p d)+(A A / t r)+(I A / n s))]$.

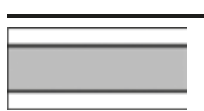

$\mathrm{EA} / \mathrm{nd}$

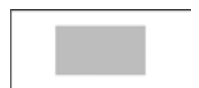

$\mathrm{AA} / \mathrm{nr}$

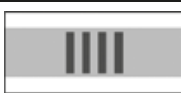

$\mathrm{IA} / \mathrm{s}$

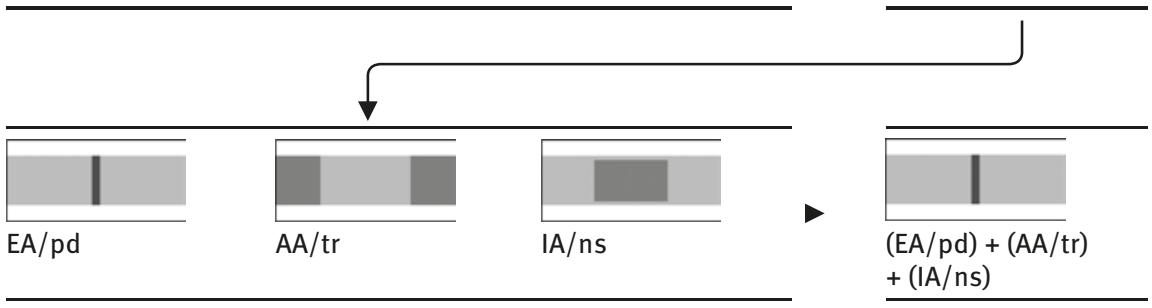

\subsubsection{Delimitation Schema 2/8, 8, 8, ...: [((EA/nd) + (AA/nr) + (IA/s)) >} $((E A / p d)+(A A / n r)+(I A / n s)),((E A / p d)+(A A / n r)+(I A / n s)),((E A / p d)+$ $(A A / n r)+(I A / n s)), \ldots]$

(17) It. Guardai dalla finestra e vidi la pioggia che stava [Imp.] cadendo. ${ }^{6}$ [stare + Ger. $]$

'I looked out the window and saw the rain that was falling.'

6 This example is particularly suitable for further investigation of a question already addressed in \$3.5, where the following examples were compared: (11) It. La pioggia cade leggera sulla terra and (11') It. Il sasso cade pesantemente nell'acqua. So far, the examples have been commented according to traditional terminology. Now, these can be described according to the model presented here: while states of affairs such as those in (11) represent a DS of the type $2 / 8,8,8 \ldots$, i.e., a combination of the following aspectual basic conceptualisations: $[((\mathrm{EA} / \mathrm{nd})+(\mathrm{AA} / \mathrm{nr})+(\mathrm{IA} / \mathrm{s}))>$ $((\mathrm{EA} / \mathrm{pd})+(\mathrm{AA} / \mathrm{nr})+(\mathrm{IA} / \mathrm{ns})),((\mathrm{EA} / \mathrm{pd})+(\mathrm{AA} / \mathrm{nr})+(\mathrm{IA} / \mathrm{ns})),((\mathrm{EA} / \mathrm{pd})+(\mathrm{AA} / \mathrm{nr})+(\mathrm{IA} / \mathrm{ns})), \ldots]$, those such as in (11') represent a DS of the type $2 / 8$, i.e., with the combination $[((\mathrm{EA} / \mathrm{nd})+(\mathrm{AA} / \mathrm{nr})$ $+(\mathrm{IA} / \mathrm{s}))>((\mathrm{EA} / \mathrm{pd})+(\mathrm{AA} / \mathrm{nr})+(\mathrm{IA} / \mathrm{ns}))]$. Of course, different elements contribute to this, not least the first arguments in the sentences ('rain' and 'stone', respectively): the speaker has learned in two different experiential contexts that the temporal (aspectual) meaning of 'to fall' in connection with 'rain' has durative and iterative traits (the rain falls continuously over time, because 'rain' is a collective noun that subsumes countable entities), whereas in connection with 'stone' it conveys punctuality. 
(18) Fr. Le voleur était [Imp.] en train de préparer le plan de braquage de la banque depuis longtemps. [être en train de + Inf.]

'The thief had been preparing the plan for the bank robbery for a long time.'

(19) Sp. Juan anda [Pres.] haciendo cosas que no puedo impedir. [andar + Ger.] 'Juan is going around doing things that I cannot prevent.'

(20) Cat. Fa tres hores que el Leo estava [Imp.] menjant galetes. [estar + Ger.] 'Leo's been eating biscuits for three hours.'

The states of affairs in examples (17)-(20) represent the following combination of aspectual basic conceptualisations: ${ }^{7}$

First level:

a) externally non-delimited (EA/nd)

b) not relevant to adjacency $(\mathrm{AA} / \mathrm{nr})$

c) internally subdivided (IA/s)

Second level:

a') externally punctually delimited (EA/pd)

b') not relevant to adjacency (AA/nr)

c') not internally subdivided (IA/ns)

a”) externally punctually delimited (EA/pd)

b’) not relevant to adjacency (AA/nr)

c") not internally subdivided (IA/ns)

a”’) externally punctually delimited (EA/pd)

b"’') not relevant to adjacency (AA/nr)

c",') not internally subdivided (IA/ns)

a",’) $\ldots$

7 The aspectual structuring of states of affairs of this type corresponds to what is called "progressive-durative" in traditional studies (see Bertinetto 1995a, among others). This delimitation schema, in which quantity also plays a role due to the multiple focussing of different moments $t_{x 1}, t_{x 2}, \ldots t_{x n}$, is also suitable for describing iteration in states of affairs. That not only pure iteration but also habit can be represented in the state of affairs has nothing to do with the purely temporal structure of the state of affairs, so this is not only related to aspectuality and quantity. 
In (17)-(20), on the first level of the combination of aspectual basic conceptualisations, a) neither a starting point $t_{x}$ nor an endpoint $t_{y}$ of the respective entire states of affairs is focussed - i.e., neither the beginning nor the end of the falling of the rain in (17), of the preparation of the plan for the bank robbery in (18), of Juan's repeatedly doing things that I cannot prevent in (19), or of Leo's eating biscuits for three hours in (20). In other words, the respective states of affairs are not presented as completed. Therefore, b) it is logically impossible to find relevance for their adjacencies. Finally, c) (substantially) different moments $t_{x 1}$, $t_{x 2}, \ldots t_{x n}$ can be perceived in (17) in the falling of the rain. The rain fell in all these $t_{x 1}, t_{x 2}, \ldots t_{x n}$ and each of these moments can be viewed and represented individually and in isolation, i.e., in each $t_{x 1}$ the rain fell differently (stronger, lighter etc.) than in $t_{x 2}$, and the same can be said for the preparation of the plan for the bank robbery in (18) and for the states of affairs in (19) and (20).

Here, too, it is precisely this realisation of internal aspectuality of the entire state of affairs that is the prerequisite for further perspectivisation within the situation frame, because only if, as is the case here, further subdivision points or boundaries in the temporal structuring of the state of affairs can be set, only if discrete temporal subintervals $t_{x 1}, t_{x 2}, \ldots t_{x n}$ can be perceived, will it be possible to further focus one or - as is the case in (17)-(20) - several such subintervals. That several - but each separately $-t_{x 1}, t_{x 2}, \ldots t_{x n}$ are further focussed in the state of affairs, and that each of these moments sets temporal boundaries around which a subframe is formed within the entire frame, reflects the structuring of an iterated state of affairs, because, as we will see, each $t_{\mathrm{x} 1}$ is represented as a subframe with delimited aspectuality, i.e., as completed, and the next $t_{x 2}$ can only be a new subframe (also represented as completed). ${ }^{8}$ Speakers know from their world knowledge that rain is a collective noun consisting of individual drops that fall individually to the ground, and when the falling of rain is represented as in (17), then it is done in such a way that the (several, iterated) individual moments of falling are themselves focussed in the state of affairs presented as a whole. These moments, around each of which a subframe is formed with reference to the entire state of affairs, are now characterised by a') external punctual aspectuality (EA/pd), b') no adjacency relevance (AA/nr) and c') no subdivision of their internal aspectuality (IA/ns). Every moment $t_{\mathrm{x} 1}$, $t_{x 2}, \ldots t_{x n}$ of the falling of the rain is focussed along with its boundaries (thus we have different $\left.\delta t_{x 1}, \delta t_{x 2}, \ldots \delta t_{x n}\right)$; no fallen drop of rain determines the

8 DS $2 / 8,8,8, \ldots-$ DS $7 / 11,11,11, \ldots$ are cases which are traditionally treated as degree achievement; see also §5.2.2.6. 
beginning nor the end of the rain ( $t_{x 1}$ does not affect $t_{x 1-1}$ or $t_{x 1+1}$ in any way); nor can any $\delta t_{x 1}, \delta t_{x 2}, \ldots \delta t_{x n}$, in which the rain has fallen, be internally subdivided either. The situation is similar in (18), where in the state of affairs presented as a whole the individual - multiple - moments of preparation for the bank robbery are presented and each is further focussed, or in (19), where Juan's doing things that the speaker cannot prevent is also presented in its individual constitutive, further focussed moments.

The aspectual contents described are conveyed here by the following different forms: verbal periphrases of the type STARE + gerund in (17) and (20) or of the type être en train de + infinitive in (18) (with the auxiliary verb in the imperfect), or by the special verb periphrasis, common only in Spanish, andar + gerund in (19) (with the auxiliary verb in the present tense) in combination with the verbs 'falling of the rain', 'preparing a plan', 'doing things' and 'eating biscuits' (and their first and, in part, further arguments). An important role is played here by the arguments cosas in (19) and galetes in (20) appearing in the plural and without definite articles. Table (6) illustrates this delimitation schema $(2 / 8,8,8, \ldots)$ :

Tab. 6: Delimitation Schema 2/8, 8, 8, . . : $[((E A / n d)+(A A / n r)+(I A / s))>((E A / p d)+(A A / n r)+$ $(I A / n s)),((E A / p d)+(A A / n r)+(I A / n s)),((E A / p d)+(A A / n r)+(I A / n s)), \ldots]$.

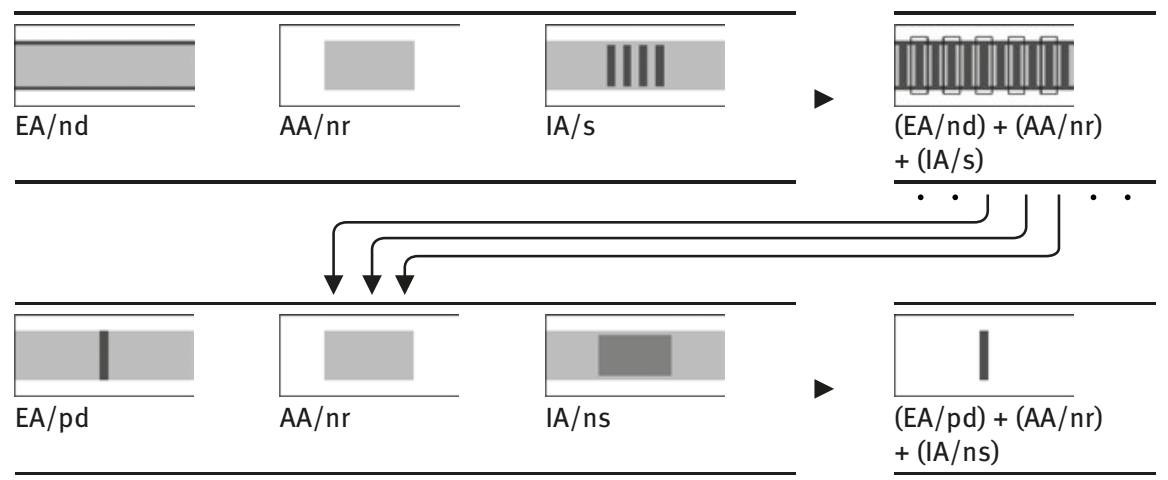

6.2.2.6 Delimitation Schema 2/9, 9, 9, ...: [((EA/nd) + (AA/nr) + (IA/s)) > $((E A / p d)+(A A / f r)+(I A / n s)),((E A / p d)+(A A / f r)+(I A / n s)),((E A / p d)+$ $(\mathrm{AA} / \mathrm{fr})+(\mathrm{IA} / \mathrm{ns})), \ldots .$.

(21) It. Il giudice viene [Pres.] raccogliendo prove contro l'imputato. [venire + Ger.] 'The judge has been going about gathering evidence against the defendant.' 
(22) Fr. Je viens [Prés.] ramassant mes affaires depuis un mois. ${ }^{9}$ [venir + Ger.] 'I have been gathering my things for a month.'

(23) Sp. Te lo vengo [Pres.] diciendo desde el principio. [venir + Ger.] 'I've been telling you this from the beginning.'

(24) Cat. Fa molt de temps que vinc [Pres.] parlant d'aquest problema. [venir + Ger.] 'I have been talking about this problem for a long time.'

The states of affairs in examples (21)-(24) represent the following combination of aspectual basic conceptualisations (for reasons of space only one $t_{x 1}$ of the sublevel is shown here by way of example):

First level:

a) externally non-delimited (EA/nd)

b) not relevant to adjacency $(\mathrm{AA} / \mathrm{nr})$

c) internally subdivided (IA/s)

Second level:

a') externally punctually delimited (EA/pd)

b') with final adjacency relevance (AA/fr)

c') not internally subdivided (IA/ns)

a’) $\ldots$

In (21)-(24), on the first level of the combination of aspectual basic conceptualisations, a) neither a starting point $t_{x}$ nor an endpoint $t_{y}$ of the respective entire states of affairs is focussed - i.e., neither the beginning nor the end of the judge gathering (pieces of) evidence in (21), the gathering of my things in (22), the fact that I've been telling you this since the beginning in (23) or that I've been

9 Coseriu (1976) and Schwall (1991), referring to Coseriu, point out that this type of verbal periphrasis is used in this way in Modern French, but also that it is extremely rare. Attention has already been drawn to the fact that the frequency of this verbal periphrasis had already drastically decreased by the Middle French period. A corpus-oriented study would offer insights into current usage and would therefore be highly desirable. On French verbal periphrases in general see Gougenheim (1929) and also Laca (2004a), Mitko (1999 and 2000) and Pusch (2003a); on French verbal periphrases in previous stages of the language see Werner (1980). 
talking about this problem for some time in (24). In other words, each of these entire states of affairs is presented as not completed. Therefore, it is logically impossible b) to find the relevance of this type of state of affairs for its adjacency. Finally, c) in the gathering of evidence in (21) (substantially) different moments $t_{x 1}, t_{x 2}, \ldots t_{x n}$ can be perceived, and the judge gathers different pieces of evidence in all these $t_{x 1}, t_{x 2}, \ldots t_{x n}$ and each of these moments can be viewed and represented individually and in isolation, i.e., in each $t_{x 1}$ the gathering is different than in $t_{x 2}$ and the same can be said for my gathering in (22) and for the pluriphasic states of affairs in (23) and (24).

It is precisely this realisation of internal aspectuality of the entire state of affairs that is the prerequisite for further perspectivisation within the situation frame. Here, too, it is possible to further focus one or several temporal subintervals $t_{x 1}, t_{x 2}, \ldots t_{x n}$. That each of these $t_{x 1}, t_{x 2}, \ldots t_{x n}$ represents a temporal boundary around which a subframe is formed within the entire frame reflects the structuring of an iterated state of affairs (the speaker knows from his/her knowledge of the world that the gathering of evidence consists in the repeated gathering of individual pieces of evidence and represents this by means of this aspectual structuring). Each of these subframes expresses the following combination of aspectual basic conceptualisations: it is a') externally punctually delimited (EA/pd), the initial and final boundaries of each $t_{x 1}, t_{x 2}, \ldots t_{x n}$ in which the judge collects evidence against the defendant are focussed and these boundaries coincide (thus, they represent different $\delta \mathrm{t}_{\mathrm{x} 1}, \delta \mathrm{t}_{\mathrm{x} 2}, \ldots \delta \mathrm{t}_{\mathrm{xn}}$ ); every single moment $t_{x 1}$ of gathering evidence has $b$ ') final adjacency relevance (AA/fr), i.e., it influences its previous adjacency $\left(t_{x 1-1}\right)$ by determining its end (the end of the previous adjacency of the subframe, that is, not that of the entire state of affairs); finally, each $\delta t_{x 1}, \delta t_{x 2}, \ldots \delta t_{x n}$ in which the judge has collected evidence is c') not internally subdivided. The states of affairs in (22)-(24) can be analysed similarly. The aspectual contents described are here conveyed by the following forms: verbal periphrases of the type VENIRE + gerund in (21)-(24) (with the auxiliary verbs in the present tense) in combination with the verbs 'to gather evidence', 'to gather my things', 'to tell' and 'to talk about this problem' (and their first and, in part, further arguments). Table (7) illustrates this delimitation schema $(2 / 9,9,9, \ldots)$ : 
Tab. 7: $D S 2 / 9,9,9, \ldots:[((E A / n d)+(A A / n r)+(I A / s))>((E A / p d)+(A A / f r)+(I A / n s)),((E A / p d)+$ $(A A / f r)+(I A / n s)),((E A / p d)+(A A / f r)+(I A / n s)), \ldots]$.

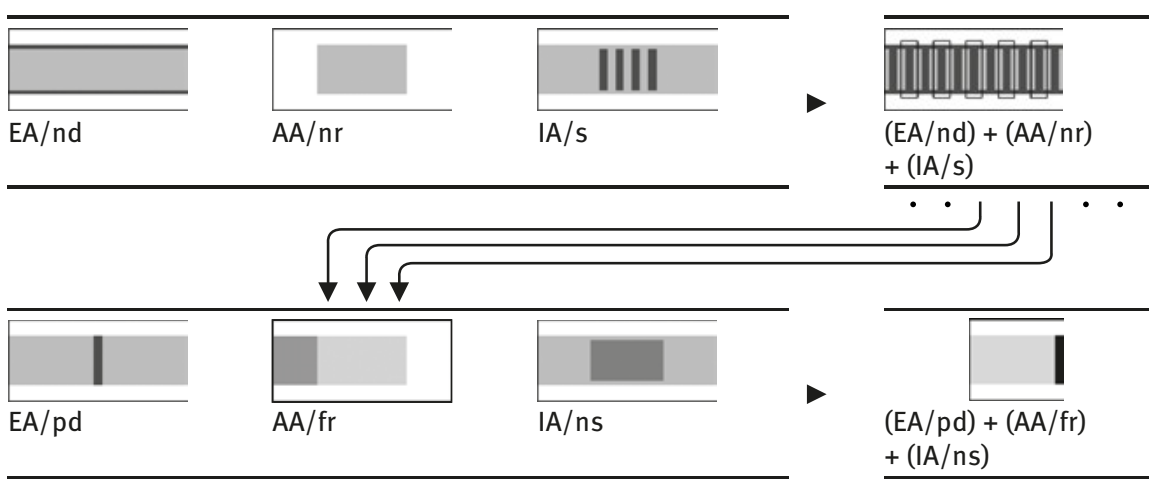

6.2.2.7 Delimitation Schema 2/10, 10, 10, ...: $[((E A / n d)+(A A / n r)+(I A / s))>$ $((E A / p d)+(A A / i r)+(I A / n s)),((E A / p d)+(A A / i r)+(I A / n s)),((E A / p d)+$ $(\mathrm{AA} / \mathrm{ir})+(\mathrm{IA} / \mathrm{ns})), . .$.

(25) It. Te lo vado [Pres.] dicendo da mesi! [andare + Ger.] 'I’ve been telling you that for months!'

(26) Fr. Tout doucement, il va [Prés.] s'approchant de la fenêtre. [aller + Ger.] 'Very slowly, he's been making his way towards the window.'

(27) Sp. La tormenta se va [Pres.] acercando más y más. [ir + Ger.] 'The storm is getting closer and closer.'

(28) Cat. Els grups parlamentaris s'anaven [Pres.] asseient a la taula de treball. [anar + Ger.]

'The groups of parliamentarians have been sitting at the negotiating table.'

The states of affairs in examples (25)-(28) represent the following combination of aspectual basic conceptualisations:

First level:

a) externally non-delimited (EA/nd)

b) not relevant to adjacency $(\mathrm{AA} / \mathrm{nr})$

c) internally subdivided (IA/s) 
Second level:

a') externally punctually delimited (EA/pd)

b') with initial adjacency relevance (AA/ir)

c') not internally subdivided (IA/ns)

a’) $\ldots$

In (25)-(28), on the first level of the combination of aspectual basic conceptualisations, a) neither a starting point $t_{x}$ nor an endpoint $t_{y}$ of the respective entire states of affairs is focussed - i.e., neither the beginning nor the end of my telling you about it in (25), of his making his way to the window in (26), of the storm approaching in (27), or of the parliamentarians' sitting at the negotiating table in (28). The respective entire states of affairs (thus presented as not completed) therefore b) do not have relevance for their respective adjacencies. Finally, c) (substantially) different moments $t_{x 1}, t_{x 2}, \ldots t_{x n}$ can be perceived in the approaching of the storm in (27) and each of these moments can be viewed and represented individually and in isolation, i.e., in $t_{x 1}$ the storm is approaching differently to $t_{x 2}$, and the same can be said for the pluriphasic states of affairs in (25), (26) and (28).

It is precisely this realisation of internal aspectuality of the entire state of affairs that is the prerequisite for further perspectivisation within the situation frame. In (25)-(28) several temporal divisions $t_{x 1}, t_{x 2}, \ldots t_{x n}$ are further focussed, and around each of these $t_{x 1}, t_{x 2}, \ldots t_{x n}$ a subframe is formed within the whole frame (an iterated state of affairs is presented in each case, as explained in more detail above). Each of these subframes expresses the following combination of aspectual basic conceptualisations: they are a') externally punctually delimited (EA/pd), the initial and final boundaries of all the $t_{x 1}, t_{x 2}, \ldots t_{x n}$ in which, for example, the storm approaches in (27) are focussed and these boundaries coincide (and are therefore different $\delta \mathrm{t}_{\mathrm{x} 1}, \delta \mathrm{t}_{\mathrm{x} 2}, \ldots \delta \mathrm{t}_{\mathrm{xn}}$ ). Every single moment $t_{x 1}$ of the approaching of the storm has b') initial adjacency relevance (AA/ir), that is, it influences its subsequent adjacency $t_{x 1+1}$ by determining its beginning (again, of course, only the beginning of the subframe, not the beginning of the subsequent adjacency of the whole state of affairs). In each $t_{x 1+1}$, $t_{x 2+1}, \ldots t_{x n+1}$ the storm is closer than in each $t_{x 1}, t_{x 2}, \ldots t_{x n}$. Finally, each moment $\delta t_{x 1}, \delta t_{x 2}, \ldots \delta t_{x n}$ in which the storm is approaching is $\left.c^{\prime}\right)$ not internally subdivided. The states of affairs in (25), (26) and (28) can be analysed likewise.

The aspectual contents described above are conveyed through the following forms: verbal periphrases of the type VADERE + gerund in (25)-(28) (with the auxiliary verb in the present tense in all cases) in combination with the verbs 'to say for months', 'to make his way to the window', 'to approach', and 'to sit 
at the table' (and their first and, in part, further arguments). Table (8) illustrates this delimitation schema $(2 / 10,10,10, \ldots)$ :

Tab. 8: $D S 2 / 10,10,10 \ldots:[((E A / n d)+(A A / n r)+(I A / s))>((E A / p d)+(A A / i r)+(I A / n s)),((E A / p d)+$ $(A A / i r)+(I A / n s)),((E A / p d)+(A A / i r)+(I A / n s)), \ldots]$.

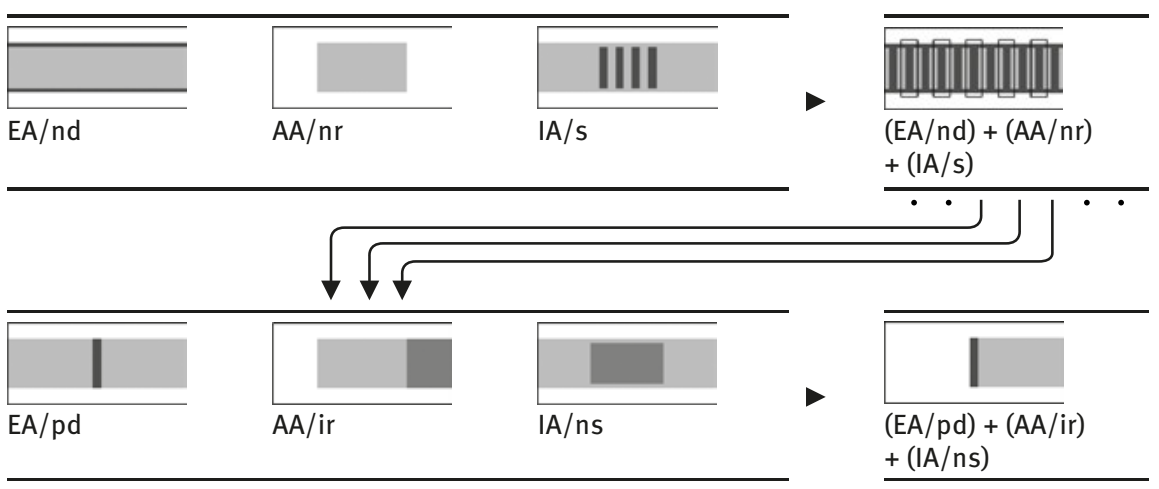

6.2.2.8 Delimitation Schema 2/11, 11, 11, ...: $[((E A / n d)+(A A / n r)+(I A / s))>$ $((E A / p d)+(A A / t r)+(I A / n s)),((E A / p d)+(A A / t r)+(I A / n s)),((E A / p d)+$ $(\mathrm{AA} / \mathrm{tr})+(\mathrm{IA} / \mathrm{ns})), \ldots]$

(29) It. Ho perso ancora una volta le chiavi: è segno che sto [Pres.] impazzendo. [stare + Ger.]

'I have lost my keys once again: it's a sign that I'm going crazy.'

(30) Fr. La jeune danseuse rougissait [Imp.] toujours plus, alors que Luca l'observait durant sa danse. ${ }^{10}$

'The young dancer blushed more and more, while Luca watched her during her dance.'

(31) Sp. Tengo la impresión de que María se vuelve [Pres.] loca cada vez más. 'I have the impression that Maria is going more and more crazy.'

(32) Cat. M'estic [Pres.] enamorant del Joan cada dia més i més. [estar + Ger.] 'I'm falling in love with Joan more and more every day.'

10 Cf. the Spanish example (15) in §6.2.2.4. The presence or absence of an adverb in interaction with the other elements in the situation frame influences the entire aspectual structuring. 
The states of affairs in examples (29)-(32) represent the following combination of aspectual basic conceptualisations:

First level:

a) externally non-delimited (EA/nd)

b) not relevant to adjacency $(\mathrm{AA} / \mathrm{nr})$

c) internally subdivided (IA/s)

Second level:

a') externally punctually delimited (EA/pd)

b') with initial and final (transformative) adjacency relevance (AA/tr)

c') not internally subdivided (IA/ns)

a') $\ldots$

In (29)-(32), on the first level of the combination of aspectual basic conceptualisations, a) neither a starting point $t_{x}$ nor an endpoint $t_{y}$ of going crazy in (29) and (31), the dancer's increasing blushing in (30), or of me falling more and more in love with Joan in (32) is focussed. The respective entire states of affairs (thus presented as not completed) therefore $b$ ) have no relevance for their respective adjacencies. Finally, c) in the going crazy in (29) and (31), in the increasing blushing of the dancer in (30) and in me gradually falling in love with Joan in (32), (substantially) different moments $t_{x 1}, t_{x 2}, \ldots t_{x n}$ can be perceived. In (29), for example, my going crazy in each of these moments can be viewed and represented individually and in isolation, i.e., in each $t_{x 1}$ the going crazy is different from the one in $t_{x 2}$ (this also goes for the pluriphasic states of affairs in (30)-(32)).

That (substantially) different moments $t_{x 1}, t_{x 2}, \ldots t_{x n}$ can be perceived in the respective states of affairs is precisely the prerequisite for their further perspectivisation within the situation frame. In (29) several $t_{x 1}, t_{x 2}, \ldots t_{x n}$ of my going crazy are further focussed and around each of these $t_{x 1}, t_{x 2}, \ldots t_{x n}$ a subframe is formed within the entire frame, which expresses the following combination of aspectual basic conceptualisations: it is a') externally punctually delimited (EA/pd), the initial and final boundaries of every $t_{x 1}, t_{x 2}, \ldots t_{x n}$ in which I am going crazy are focussed and these boundaries coincide (thus, they are $\delta t_{x 1}, \delta t_{x 2}, \ldots \delta t_{x n}$ ). Every single moment $t_{x 1}$ of my going crazy has $b$ ') initial and final (thus transformative) adjacency relevance (AA/tr), i.e., each influences its previous $\left(t_{x 1-1}\right)$ and subsequent $\left(\mathrm{t}_{\mathrm{x} 1+1}\right)$ adjacencies by determining, respectively, its end and its beginning. That is to say, in every moment $t_{x 1-1}, t_{x 2-1}, \ldots t_{x n-1} I$ am a little less crazy than I am in every $t_{x 1}, t_{x 2}, \ldots t_{x n}$ and even less crazy than I will be in every $t_{x 1+1}, t_{x 2+1}, \ldots$ $t_{x n+1}$. Every $\delta t_{x 1}, \delta t_{x 2}, \ldots \delta t_{x n}$ in which I'm going crazy is finally c') not internally subdivided. The states of affairs in (30)-(32) can be analysed similarly. 
The aspectual contents described above are conveyed through very different forms and constructions, and it is worthwhile looking at the components of each example sentence individually. In (29) we have a verbal periphrasis of the type STARE + gerund (with the auxiliary verb in the present tense) in combination with the intransitive verb impazzire 'going crazy', which the speaker's world knowledge informs is a gradual state of affairs. In (30), too, a complex, gradual state of affairs is shown, which can be represented by DS $2 / 11,11,11, \ldots$. This is expressed not only by the first part of the sentence (la jeune danseuse rougissait toujours plus) with the intransitive verb 'to blush' in the imperfect (anchored in the speaker's world knowledge as a gradual state of affairs), reinforced by the adverbial toujours plus 'ever more', but also by the second part of the sentence (alors que Luca l'observait durant sa danse), which provides a temporal frame within which the 'blushing' is represented in its progression. In (31) we again find an intransitive verb, volverse loco 'to go crazy', but with present tense morphological marking, and the adverbial cada vez más, which considerably reinforces the idea of graduality and escalation. Finally, (32) contains the verbal periphrasis STARE + gerund (in which the auxiliary verb is in the present tense) in combination with the intransitive verb enamorarse (also recognised as a gradual state of affairs in the speaker's world knowledge $)^{11}$ and the adverbial cada dia més $i$ més, which emphasises this further and more strongly. Table (9) illustrates this delimitation schema $(2 / 11,11,11, \ldots)$ :

Tab. 9: $D S$ 2/11, 11, 11, . . : [((EA/nd) + (AA/nr) + (IA/s)) > ((EA/pd) + (AA/tr) + (IA/ns)), ((EA/pd) $+(A A / t r)+(I A / n s)),((E A / p d)+(A A / t r)+(I A / n s)), \ldots .$.

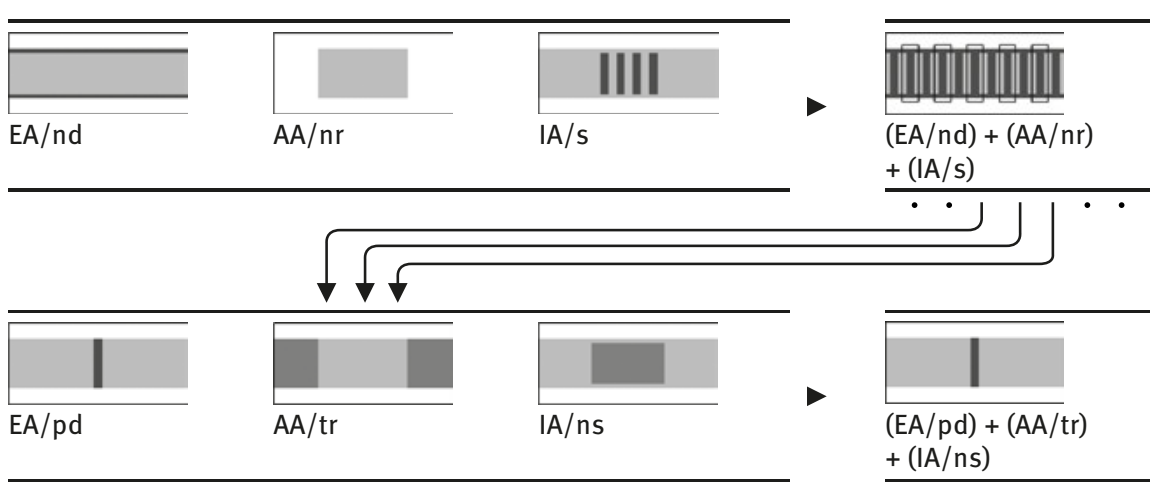

11 The verb 'to fall in love' is, of course, polysemous: 'to fall in love at first sight' is anchored differently in the speaker's world knowledge in other experiential contexts. 
6.2.2.9 Delimitation Schema 4/8, 8, 8, ... : [((EA/d) + (AA/nr) + (IA/s)) > ((EA/ pd $)+(A A / n r)+(I A / n s)),((E A / p d)+(A A / n r)+(I A / n s)),((E A / p d)+(A A /$ $n r)+(I A / n s)), \ldots]$

(33) Sp. Estuve [Perf. Sim.] comiendo toda la noche. [estar + Ger.] 'I've been eating all night.'

(34) Cat. La Rosina va estar [Pret. Perf. Per.] cantant tot el dia. [estar + Ger.] 'Rosina has been singing all day.'

The states of affairs in examples (33) and (34) represent the following combination of aspectual basic conceptualisations:

First level:

a) externally delimited (EA/d)

b) not relevant to adjacency $(\mathrm{AA} / \mathrm{nr})$

c) internally subdivided (IA/s)

Second level:

a') externally punctually delimited (EA/pd)

b') not relevant to adjacency (AA/nr)

c') not internally subdivided (IA/ns)

a") $\ldots$

In (33) and (34), on the first level of the combination of aspectual basic conceptualisations, a) both the starting point $t_{x}$ and the endpoint $t_{y}$ of the respective entire states of affairs - i.e., both the beginning and end of my eating (observed in its progression) in (33) (because before the night I was not eating and afterwards I will no longer be eating) and of Rosina's singing in (34) - are focussed. In other words, the respective states of affairs are presented as completed and b) irrelevant for their adjacencies (for neither my eating nor Rosina's singing determines the end or the beginning of their previous or subsequent adjacencies). Finally, c) in the nocturnal eating (as in Rosina's singing) substantially different moments $t_{\mathrm{x} 1}, t_{\mathrm{x} 2}, \ldots t_{\mathrm{xn}}$, in which I was eating (and Rosina was singing) can be perceived.

Here, too, it is precisely this realisation of internal aspectuality of the entire state of affairs that is the prerequisite for further perspectivisation within the 
situation frame. Several $t_{x 1}, t_{x 2}, \ldots t_{x n}$ - but each individually - in the entire states of affairs are further focussed (and it is exactly this that permits a dynamic representation of the states of affairs); each of these moments represents a temporal boundary around which a subframe is formed within the entire situation frame (so that there are as many subframes as there are $t_{x 1}, t_{x 2}, \ldots t_{x n}$ ) and each has the following delimitation schema: a') external punctual aspectuality (EA/pd), b') not relevant to adjacency (AA/nr) and c') no subdivision of their internal aspectuality (IA/ns). Every $t_{x 1}, t_{x 2}, \ldots t_{x n}$ of my eating is focussed together with its coinciding boundaries, since each time a moment that is individually isolated and considered completed is focussed (so they are different $\left.\delta \mathrm{t}_{\mathrm{x} 1}, \delta \mathrm{t}_{\mathrm{x} 2}, \ldots \delta \mathrm{t}_{\mathrm{xn}}\right)$; none of the moments during the eating affects the beginning of the next moment of eating nor the ending of the previous moment (thus, $t_{x 1}$ does not affect $t_{x 1-1}$ nor $t_{x 1+1}$ in any way); each $\delta t_{x 1}, \delta t_{x 2}, \ldots \delta t_{x n}$ during which $I$ was eating all night cannot logically be internally subdivided. A similar analysis can be given for (34).

The aspectual contents described above are conveyed in examples (33) and (34) by a verbal periphrasis of the type STARE + gerund with the auxiliary verb in the Pretérito Indefinido and Pretèrit Perfet Perifràstic, respectively. The combination with the perfect tenses is a peculiarity of the Ibero-Romance construction of this type (cf. §6.3.3) and has no correspondence in Italian and French. ${ }^{12}$ This construction interacts here with the verbs 'to eat' and 'to sing' (and their first arguments) and with their respective adverbials toda la noche and tot el dia, which reinforce the representation of the duration of the iterated state of affairs.

Table (10) illustrates this combination of aspectual basic conceptualisations (DS 4/8, 8, 8, ..):

12 Herein lies another advantage of the onomasiological model presented here. Aside from the observation, quite possible from a semasiological perspective, that only the IberoRomance estar-periphrasis occurs with perfective tenses such as the Spanish Preterito Indefinido and the Catalan Pretèrit Perfet Perifràstic etc., a precise position in the conceptual system of aspectuality can now be assigned to this Ibero-Romance idiosyncrasy (and the gap in the other Romance languages accounted for) (cf. the DS in §§6.2.2.9-6.2.2.12 and the analysis there of examples (33)-(40)). 
Tab. 10: Delimitation Schema 4/8, 8, 8, . : $:[((\mathrm{EA} / \mathrm{d})+(\mathrm{AA} / \mathrm{nr})+(\mathrm{IA} / \mathrm{s}))>((\mathrm{EA} / \mathrm{pd})+(\mathrm{AA} / \mathrm{nr})+$ $(I A / n s)),((E A / p d)+(A A / n r)+(I A / n s)),((E A / p d)+(A A / n r)+(I A / n s)), \ldots]$.

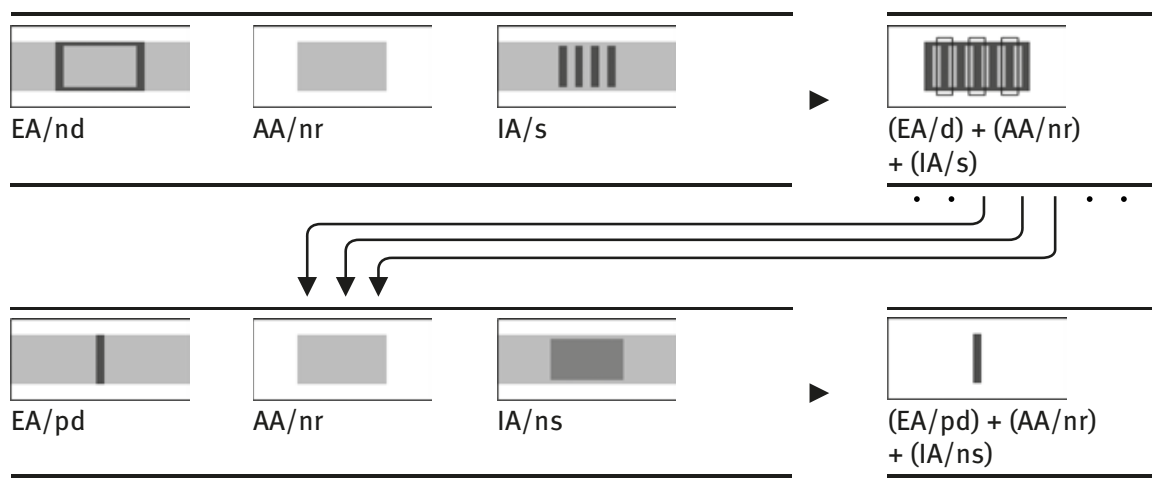

6.2.2.10 Delimitation Schema 5/9, 9, 9, ... : [((EA/d) + (AA/fr) $+(I A / s))>((E A /$ pd $)+(A A / f r)+(I A / n s)),((E A / p d)+(A A / f r)+(I A / n s)),((E A / p d)+(A A /$ fr) $+(I A / n s)), \ldots]$

(35) Sp. El material de construcción estuvo [Perf. Sim.] llegando por meses. [estar + Ger.] 'Building material has been arriving for months.'

(36) Cat. Els passatgers van [Pret. Perf. Per.] estar embarcant tot el dia. [estar + Ger.] 'The passengers have been embarking all day long.'

The states of affairs in examples (35) and (36) represent the following combination of aspectual basic conceptualisations:

First level:

a) externally delimited (EA/d)

b) with final adjacency relevance (AA/fr)

c) internally subdivided (IA/s)

Second level:

a') externally punctually delimited (EA/pd)

b') with final adjacency relevance (AA/fr)

c') not internally subdivided (IA/ns)

a") $\ldots$ 
In (35) and (36), on the first level of the combination of aspectual basic conceptualisations, $a$ ) both the starting point $t_{x}$ and the endpoint $t_{y}$ of the respective entire states of affairs - i.e., both the beginning and the end of the arriving of the building material in (35) (considered continuously in its progression) and the embarking of the passengers in (36) - are focussed. In other words, the respective states of affairs are presented as completed and have b) final adjacency relevance (because both the arriving of the building material and the one-daylong embarking of the passengers determine the end of their respective previous adjacencies: when the material has (completely) arrived, it will no longer arrive; when all passengers have embarked, they will no longer do so). Finally, c) substantially different moments $t_{x 1}, t_{x 2}, \ldots t_{x n}$ can be perceived in the arriving of the building material (as well as in the embarking of the passengers), in which the building material has arrived (and the passengers have embarked).

Here, too, it is precisely this realisation of internal aspectuality of the entire state of affairs that is the prerequisite for further perspectivisation within the situation frame. Several - but each one separately $-t_{x 1}, t_{x 2}, \ldots t_{x n}$ in the entire states of affairs are further focussed (and it is exactly this which permits a dynamic representation of the states of affairs). Each of these moments represents a temporal boundary around which a subframe is formed within the entire situation frame (so that there are as many subframes as $t_{x 1}, t_{x 2}, \ldots t_{x n}$ ), each of which has the following delimitation schema: a') external punctual aspectuality (EA/pd), b') final adjacency relevance (AA/fr), and c') no subdivision of the internal aspectuality (IA/ns). Each $t_{x 1}, t_{x 2}, \ldots t_{x n}$ of the arriving of the building material is focussed together with its coinciding boundaries, since each time a moment that is individually isolated and considered completed is focussed (thus, there are different $\delta \mathrm{t}_{\mathrm{x} 1}, \delta \mathrm{t}_{\mathrm{x} 2}, \ldots$ $\delta \mathrm{t}_{\mathrm{xn}}$, in each of which a part of the building material has arrived). Each of the moments in which a part of the building material has arrived determines the end of the previous moment of arriving (in $t_{x 1}$ there is a little more material than in $t_{x 1-1}$ ) and each $\delta t_{x 1}, \delta t_{x 2}, \ldots \delta t_{x n}$ in which the material has arrived cannot logically be internally subdivided. Example (36) can be analysed similarly.

The aspectual contents described above are conveyed in examples (35) and (36) by a verbal periphrasis of the type STARE + gerund with the auxiliary verb in the Pretérito Indefinido and Pretèrit Perfet Perifràstic, respectively, which, as already mentioned, is a special feature of this type of Ibero-Romance construction (see §6.3.3). This construction interacts here with the verbs 'arriving of the building material' and 'embarking of the passengers' (and their first arguments) and with their respective adverbials por meses and tot el dia, which intensify the representation of the duration of the iterated states of affairs.

Table (11) illustrates this combination of aspectual basic conceptualisations (DS 5/9, 9, 9,...): 
Tab. 11: Delimitation Schema 5/9, 9, 9, . : $[((\mathrm{EA} / \mathrm{d})+(\mathrm{AA} / \mathrm{fr})+(\mathrm{IA} / \mathrm{s}))>((\mathrm{EA} / \mathrm{pd})+(\mathrm{AA} / \mathrm{fr})+$ $(I A / n s)),((E A / p d)+(A A / f r)+(I A / n s)),((E A / p d)+(A A / f r)+(I A / n s)), \ldots]$.

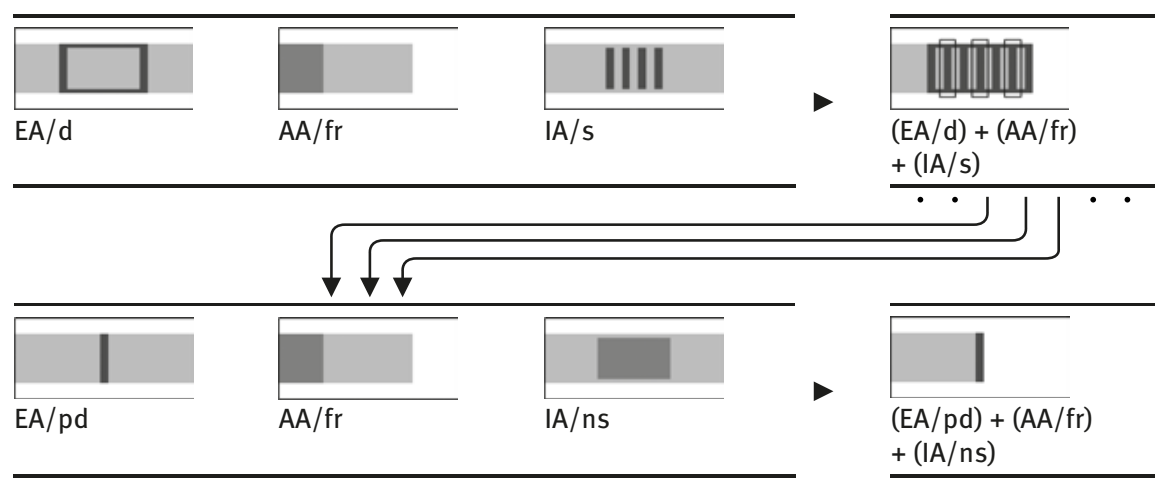

\subsubsection{Delimitation Schema 6/10, 10, 10, ... : [((EA/d) + (AA/ir) + (IA/s)) >} $((E A / p d)+(A A / i r)+(I A / n s)),((E A / p d)+(A A / i r)+(I A / n s)),((E A / p d)+$ $(A A / i r)+(I A / n s)), \ldots]$

(37) Sp. Durante tres años le estuve [Perf. Sim.] enviando cartas. [estar + Ger.] 'For three years I have been sending him letters.'

(38) Cat. Els passatgers van [Pret. Perf. Per.] estar desembarcant tot el dia. [estar + Ger.] 'The passengers have been disembarking from the ship all day long.'

The states of affairs in examples (37) and (38) represent the following combination of aspectual basic conceptualisations:

First level:

a) externally delimited (EA/d)

b) with initial adjacency relevance (AA/ir)

c) internally subdivided (IA/s)

Second level:

a') externally punctually delimited (EA/pd)

b') with initial adjacency relevance (AA/ir)

c') not internally subdivided (IA/ns)

a") $\ldots$ 
In (37) and (38), on the first level of the combination of aspectual basic conceptualisations, a) both the starting point $t_{x}$ and the endpoint $t_{y}$ of the respective entire states of affairs - i.e., both the beginning and the end of my three-year-long sending of letters (considered continuously in its progression) in (37) and the passengers' disembarking from the ship in (38) - are focussed. In other words, the entire states of affairs are presented as completed and have b) initial adjacency relevance (because both my sending of letters and the passengers' disembarking from the ship determine the beginning of their respective subsequent adjacencies: when the three years have passed, all the letters sent are on their way or have already arrived, and when all passengers have disembarked from the ship, they are all ashore). Finally, c) substantially different moments $t_{x 1}, t_{x 2}, \ldots t_{x n}$ can be perceived in the sending of the letters (as well as the disembarking from the ship), in which (different) letters have been sent (and (different) passengers have disembarked from the ship).

Here, too, it is precisely this realisation of internal aspectuality of the entire state of affairs, that is the prerequisite for further perspectivisation within the situation frame. Several - but each one separately $-t_{\mathrm{x} 1}, t_{\mathrm{x} 2}, \ldots t_{\mathrm{xn}}$ in the entire states of affairs are further focussed (and this permits a dynamic representation of the state of affairs); each of these moments represents a temporal boundary around which a subframe is formed within the entire situation frame (so that there are as many subframes as there are $t_{\mathrm{x} 1}, t_{\mathrm{x} 2}, \ldots t_{\mathrm{xn}}$ ), each corresponding to the following delimitation schema: a') external punctual aspectuality (EA/pd), b') initial adjacency relevance (AA/ir), and c') no subdivision of their internal aspectuality (IA/ns). Each $t_{x 1}, t_{x 2}, \ldots t_{x n}$ in the sending of letters is focussed together with its coinciding boundaries, since each time a moment that is individually isolated and considered completed is focussed (thus, there are different $\delta t_{x 1}, \delta t_{x 2}, \ldots \delta t_{x n}$, in all of which I have sent a letter); each of the moments in which I have sent a letter determines the beginning of the subsequent moment of the letter being on its way and is therefore no longer with me (in $t_{x 1}$ more letters have been sent than in $t_{x 1-1}$ ); each $\delta t_{x 1}, \delta t_{x 2}, \ldots \delta t_{x n}$ in which a letter was sent cannot logically be internally subdivided. Example (38) can be analysed similarly.

The aspectual contents described are conveyed in examples (37) and (38) by a verbal periphrasis of the type STARE + gerund with the auxiliary verb in the Pretérito Indefinido and Pretèrit Perfet Perifràstic, respectively. This construction interacts with the verbs 'my sending of letters' and 'the passengers leaving the ship' (and their first and possibly other arguments) and with, respectively, the adverbials durante tres años and tot el dia, which intensify the representation of the duration of the iterated states of affairs. Also important in (37) is the 
presence of an (indefinite) plural marking on cartas, which also reinforces the idea of iteration and duration.

Table (12) illustrates this delimitation schema $(6 / 10,10,10, \ldots)$ :

Tab. 12: $D S 6 / 10,10,10, \ldots$ : [((EA/d) + (AA/ir $)+(I A / s))>((E A / p d)+(A A /$ ir $)+(I A / n s)),((E A / p d)+$ $(A A / i r)+(I A / n s)),((E A / p d)+(A A / i r)+(I A / n s)), \ldots .$.

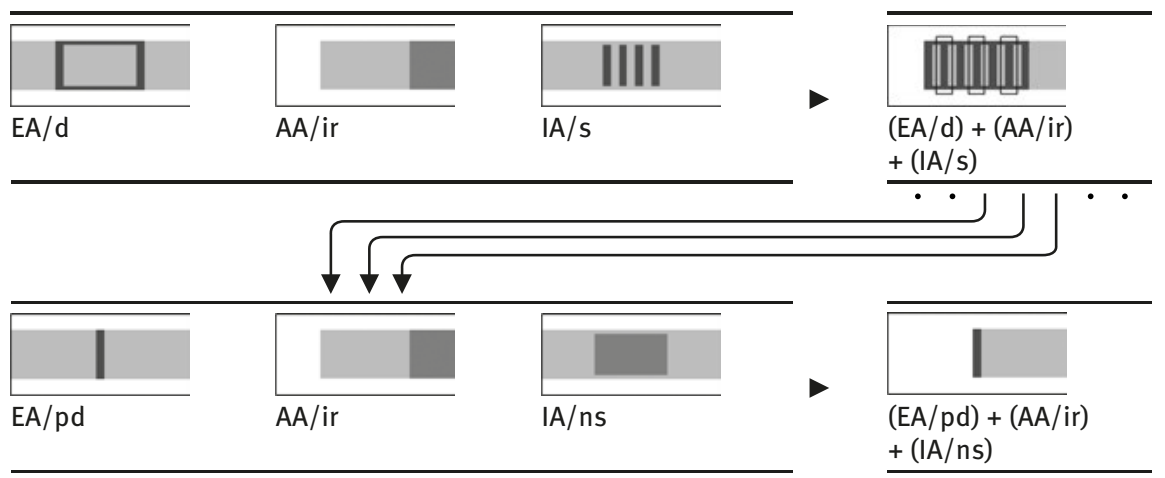

6.2.2.12 Delimitation Schema 7/11, 11, 11, ... : [((EA/d) + (AA/tr) + (IA/s)) > $((E A / p d)+(A A / t r)+(I A / n s)),((E A / p d)+(A A / t r)+(I A / n s)),((E A / p d)+$ $(\mathrm{AA} / \mathrm{tr})+(\mathrm{IA} / \mathrm{ns})), \ldots]$

(39) Sp. Durante semanas Juan estuvo [Perf. Sim.] obsesionándose buscándola. [estar + Ger.]

'For weeks Juan has been obsessed with looking for her.'

(40) Cat. Em vaig estar [Pret. Perf. Per.] enamorant d'en Daniel durant tot l'hivern. [estar + Ger.]

'I have been falling in love with Daniel throughout the whole winter.'

The states of affairs in examples (39) and (40) represent the following combination of aspectual basic conceptualisations (for reasons of space only one $t_{\mathrm{x} 1}$ of the sublevel is shown here by way of example):

First level:

a) externally delimited (EA/d)

b) with initial and final (transformative) adjacency relevance (AA/tr)

c) internally subdivided (IA/s) 
Second level:

a') externally punctually delimited (EA/pd)

b') with initial and final (transformative) adjacency relevance (AA/tr)

c') not internally subdivided (IA/ns)

a') $\ldots$

In (39) and (40), on the first level of the combination of aspectual basic conceptualisations, a) both the starting point $t_{x}$ and the endpoint $t_{y}$ of the respective entire states of affairs - i.e., both the beginning and the end of Juan's becoming obsessed (continuously observed in its progression during the weeks in which he looked for her) in (39) or my falling in love with Daniel throughout the winter in (40) - are focussed. In other words, the respective states of affairs are presented as completed and b) with initial and final (thus transformative) relevance to their adjacencies, because both Juan's becoming obsessed and my falling in love with Daniel determine the beginning and the end of their subsequent and previous adjacencies: when Juan becomes obsessed, he is obsessed after becoming obsessed and is no longer what he was before he became obsessed, namely healthy; when I fall in love, I am in love after falling in love and am no longer not in love. Finally, c) in Juan's becoming obsessed (as well as in my falling in love), substantially different moments $t_{x 1}, t_{x 2}, \ldots t_{x n}$ can be perceived, in which Juan became obsessed (and I was falling in love with Daniel).

Here, too, it is precisely this realisation of internal aspectuality of the entire states of affairs that is the prerequisite for further perspectivisation within the situation frame. Several - but each one separately $-t_{x 1}, t_{x 2}, \ldots t_{x n}$ in the entire states of affairs are further focussed (and it is this that gives the states of affairs their dynamic representation); each of these moments represents a temporal boundary around which a subframe is formed within the whole situation frame (so that there are as many subframes as $t_{x 1}, t_{x 2}, \ldots t_{x n}$ ), each of which has the following delimitation schema: a') external punctual aspectuality (EA/pd), b') transformative adjacency relevance (AA/tr) and c') no internal subdivision of the aspectuality (IA/ns). Each $t_{x 1}, t_{x 2}, \ldots t_{x n}$ of Juan becoming obsessed for weeks is focussed together with its coinciding boundaries, since each time a moment that is individually isolated and is considered completed is focussed (thus, there are different $\delta t_{x 1}, \delta t_{x 2}, \ldots \delta t_{x n}$ in which Juan respectively gets (a little more) obsessed); each of the moments in which Juan has become a little more obsessed determines the end of the previous and the beginning of the subsequent moment of becoming obsessed (in $t_{x 1-1}$ Juan is a 
little less obsessed than in $t_{x 1}$ and in every $t_{x 1+1}$ he has become a little more obsessed); therefore, each $\delta \mathrm{t}_{\mathrm{x} 1}, \delta \mathrm{t}_{\mathrm{x} 2}, \ldots \delta \mathrm{t}_{\mathrm{xn}}$ in which Juan became obsessed (more precisely, in which he was about to become a little more obsessed) cannot logically be internally subdivided. A similar analysis can be carried out for (40).

The aspectual contents described are expressed in examples (39) and (40) by a verbal periphrasis of the type STARE + gerund with the auxiliary verb in the Pretérito Indefinido and Pretèrit Perfet Perifràstic, respectively, - which is a special feature of the Ibero-Romance construction of this type (see §6.3.3). This construction interacts with the verbs 'becoming obsessed' and 'falling in love with' (and their respective first and possibly further arguments) and with the adverbials durante semanas and durant tot l'hivern, respectively, which intensify the representation of duration of the ongoing iterated state of affairs.

Table (13) illustrates this delimitation schema $(7 / 11,11,11, \ldots)$ :

Tab. 13: Delimitation Schema 7/11, 11, 11, . . : $[((E A / d)+(A A / t r)+(I A / s))>((E A / p d)+(A A / \operatorname{tr})+$ $(I A / n s)),((E A / p d)+(A A / t r)+(I A / n s)),((E A / p d)+(A A / t r)+(I A / n s)), \ldots]$.

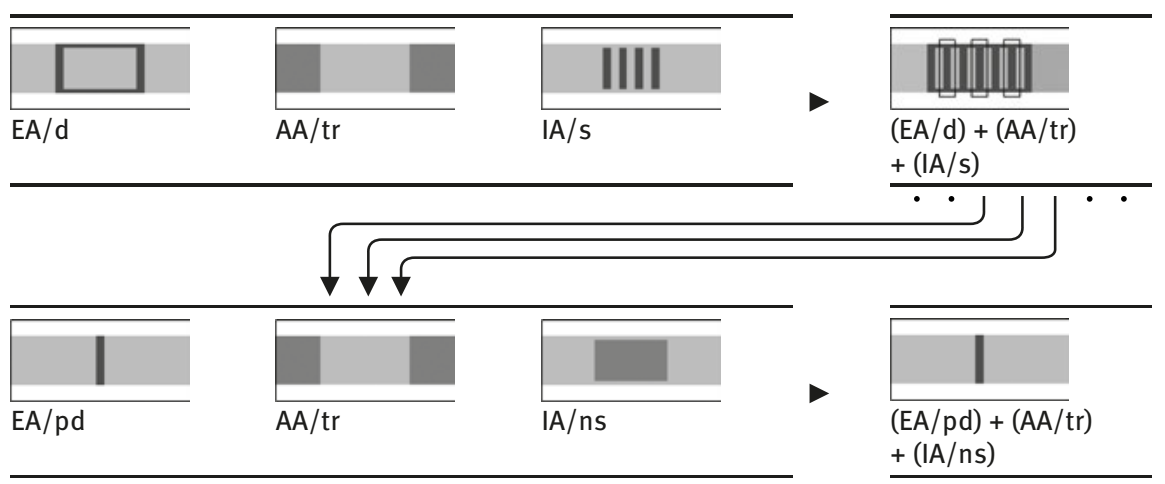

\section{3 (Aspectual) periphrastic verbal constructions}

Presentation of the second level of the system, where verbal periphrases are particularly frequent, has shown that, according to the model presented here, these constructions, which display different degrees of grammaticality or 
lexicality, also have their own place in the aspectual system of the Romance languages. In order to illustrate the significance of this, I will make a digression to look at the way verbal periphrases are generally dealt with in Romance linguistics.

The main question to be dealt with here concerns the nature of periphrastic constructions in general and aspectual verbal periphrases in particular and how they can be defined in terms of their affiliation to the lexicon or grammar. A critical examination of some traditional definitions and interpretations of verbal periphrases will also be undertaken. Special attention will be paid to the constructions examined above under DS 2/8-2/11 (§§6.2.2.1-6.2.2.4), i.e., those which express states of affairs with an aspectuality that is not externally delimited (EA/nd) and is internally subdivided (IA/s) by highlighting and further focussing on the progression of one of the constitutive moments $t_{x 1}, t_{x 2}, \ldots t_{x n}$, which are traditionally called "progressive". ${ }^{13}$ Verbal periphrases, such as the Italian construction stare + gerund, the French être en train de + infinitive, the Spanish estar + gerund and the Catalan estar + gerund will be given particular attention. To this end, their contexts and conditions of use will be analysed from a synchronic perspective, while from a diachronic perspective their degree of grammaticalisation will be discussed and their semantic paths briefly reconstructed.

\subsubsection{The relevance of the phenomenon and problems of definition}

La notion de 'périphrase verbale', traditionnelle en linguistique romane, est aussi traditionnellement mal définie. (Laca 2004a, 87)

The notion of 'verbal periphrasis', a traditional term in Romance linguistics, is also traditionally badly defined.

This short quote from Laca emphasises two important, closely-related issues: the "classical" status of verbal periphrases in the Romance linguistics tradition and the difficulty of defining the phenomenon. This section will deal with both questions in more detail.

Typical of the Romance languages is the possibility of formally expressing temporal, aspectual, modal and diathetic contents through verbal periphrastic constructions, i.e., multi-part combinations of verbs that have

13 For a characterisation of the different types of the so-called progressive see in particular §6.3.3. 
partially or completely developed into auxiliary verbs with so-called full or main verbs. ${ }^{14}$ The following types of verbal periphrases can be distinguished according to their conceptual content, i.e., the functional domain of which they are the (grammatical) categorial expression: a) temporal verbal periphrases: constructions that serve for the (more or less) grammaticalised location of states of affairs in time (as is achieved morphologically by the grammatical category tense and individual tense forms, or lexically by elements such as temporal adverbs). Examples are: Fr. aller + infinitive (as a future marker), It. avere/essere + participle, Sp. haber + participle and Cat. anar + infinitive (as past markers); b) aspectual verbal periphrases that express content referring to the temporal structure particular to the state of affairs (as realised morphologically by the grammatical category aspect and, in the Romance languages, individual forms of the past tenses, or lexically by elements such as aspectual adverbs). Examples are: Fr. être en train de + infinitive, It. venire + gerund, Sp. ir + gerund and Cat. acabar de + infinitive, as well as, of course, all forms of Lat. HABERE/ESSE + participle, if they are used in opposition to forms of the imperfect and are not understood only as temporal-deictic, i.e., temporal markers; c) diathetic verbal periphrases, which serve to express the semantic roles in the sentence. Examples of this are the passive constructions that in the Romance languages use ESSE + participle (this was expressed synthetically in Latin); d) modal verbal periphrases expressing the speaker's attitude towards the state of affairs (just as mode does grammatically and modal adverbs do lexically). Examples are: Fr. savoir + infinitive, It. avere $d a+$ infinitive, Sp. tener que + infinitive and Cat. caldre + infinitive.

The ubiquity and the special role of verbal periphrases has been recognised practically from the beginning of Romance studies and the comparative linguistic and literary study of the languages that emerged from Vulgar Latin. These constructions represent - especially as regards their analyticity - not least an important typological distinction between the Romance languages and the synthetic Latin language. ${ }^{15}$

It is therefore not surprising that such an important phenomenon has also become a traditional subject of Romance research. Examples of Romance verbal

14 Of course, these exist alongside other synthetic morphological variants in the verbal grammar, such as forms of the traditional tenses and modes.

15 The Romance tendency towards analyticity compared with the Latin tendency towards syntheticity is found not only, of course, in the verbal domain. On periphrasticity, analyticity and syntheticity (also in their relationship to each other) see Haspelmath (2000) and Schwegler (1990). 
periphrases had already appeared in Diez's first Romance grammar, ${ }^{16}$ and in recent years investigation of them has substantially increased in Romance linguistics. Semasiological and onomasiological inventories (according to individual languages or functional domains) have been complied, the contents and contexts of use of various individual verbal periphrases have been analysed, diachronic examinations of their genesis have been carried out and the relevant grammaticalisation paths reconstructed. ${ }^{17}$ We now therefore have a systematic and theoretically exacting - as well as comparative - exploration of Romance verbal periphrases to hand - a truly classic subject.

This research tradition is usually considered to have officially begun in the 1960s, particularly with the publication of Coseriu's Das romanische Verbalsystem (1976). ${ }^{18}$ In this book, Coseriu, on the one hand, provides a general explanation of Romance verbal periphrases within his general temporalaspectual verbal system, and on the other hand, deals in particular with aspectual periphrastic constructions. For he emphasises the overall - and typically - Romance character of the aspectual categories expressed with periphrases, recognises their internal connection(s) and presents them in a coherent functional system. ${ }^{19}$ The originality of this system, but also its advantages and disadvantages in terms of a general aspectual theory, have already been discussed in $\$ 1.3 .3$, although it should be briefly mentioned here that what constitute genuine aspectual categories (which are expressed by periphrases) in his system are those of Schau ('view') and Phase ('stage'). Schau refers to the category that includes consideration of the action as a whole or in its unfolding (see Coseriu 1966, 41 and 1976, 99): the speaker can view the verbal action in various ways, such as overall (i.e., as a whole), partially (in extracts), between two points of its unfolding (from a certain viewpoint), etc. Phase, on the other hand, is the category that expresses the relationship between the moment of observation and the degree of unfolding (i.e., the progression) of the verbal process under consideration.

16 See Diez (1836-44), and on Diez see Dietrich (1973, 66ff.).

17 See, among others, Bertinetto (1995a, 1995b, 1998a, 1998b and 2001), Böckle (1979 and 1984), Coseriu (1976), Dietrich (1973, 1985 and 1996), Gavarró/Laca (2002), Fernández de Castro (1999), Gómez Torrego (1988), Gougenheim (1929), Haspelmath (2000), Laca (1995, 1998, 2002b, 2004a and 2004b), Mitko (1999 and 2000), Pusch (2003a and 2003b), Roca Pons (1958), Olbertz (1998), Schlieben-Lange (1971), Squartini (1990 and 1998) and Werner (1980).

18 Lyer's writings on the topic (1934, esp. 129-211) and Wandruszka's (1969, esp. 333-349 and 355-361) ought also to be mentioned.

19 See also, in this context, Dietrich (1973) and Schlieben-Lange (1971). 
Coseriu's interpretation is mentioned here not only for the above-mentioned historical reason, but also because it underlies much of the later Romance research, such as that of Schlieben-Lange (1971) and Dietrich (1973), who apply and develop this approach in further detail in their studies of, respectively, the Occitan and Catalan verbal systems and Romance periphrastic verbal aspect. ${ }^{20}$

Classic topics are, of course, subject to recurrent discussion and usually also theoretical controversy. In the case of verbal periphrases, these emerge at the most fundamental level, i.e., the description of the subject matter itself, because there is no consensus among linguists on a definition or a classification of verbal periphrases. The problems lie on several levels. If a verbal periphrasis is considered as a whole, as a complex - i.e., multi-part - syntactic construction representing a semantic unit, it is necessary to clarify, for example, the nature of the semantic relationships between its parts and the relationships of the parts to the overall construction, and how the overall meaning of the construction emerges from its parts. Furthermore, it is also important to be clear about its status, for example, the greater or lesser degree of grammaticality or lexicality of the periphrasis in question and its components. When considering periphrases in relation to their individual parts, further problems must be addressed concerning both the auxiliary verb and the second element of the construction (usually a nonfinite verbal form, such as an infinitive, a gerund or a participle in the Romance languages). ${ }^{21}$

Some important aspects of the discussions that take place in this research area will be examined here, although I do not claim that this examination will be exhaustive, which would certainly go beyond the scope of this study and in any case other relevant works are already available (see footnote 17 in this chapter). ${ }^{22}$

20 The seemingly non-chronological order should not confuse here: Das romanische Verbalsystem, published in 1976, came out of lectures given in Tübingen in 1968/69, the first versions of which had already been given by Coseriu in Bonn in 1962 and in Tübingen in 1963. See also Coseriu's 1966 and 1968 publications. Some of the more recent studies in Romance linguistics, such as Laca's (see, e.g., 1995, 2002a and 2004a), also refer to Coseriu. An entire comparative Spanish-German grammar is based on his interpretation of the Romance verbal system, i.e., Cartagena/Gauger (1989).

21 There are, however, examples - albeit rare - of verbal periphrases whose second element contains a finite verb, namely of the type tomo y me voy or cojo y escribo in Spanish (e.g., in Cualquier día cojo y escribo un programa que vaya bien), or prendo/piglio e me ne vado in Italian (e.g., Se continui a tormentarmi così, prendo e me ne vado); see, in this context, Coseriu (1966 and 1976, 127).

22 Brief mention should be made of Haspelmath's approach (2000, see in particular 654f.), which has its origins in typological and universal research and which distinguishes between 
I shall introduce the issues dealt with in this section with Coseriu's definition:

Eine 'Periphrase' ist nämlich im eigentlichen Sinn ein sprachliches materiell mehrgliedriges Zeichen, das eine einheitliche, eingliedrige Bedeutung hat, d.h. ein gegliedertes 'Signifiant', dem aber ein einfaches 'Signifié' entspricht. (Coseriu 1976, 119)

In its main sense, a 'periphrasis' is a material multi-part linguistic sign with a uniform, onepart meaning, i.e., it is an articulated 'signifiant' that corresponds with a simple 'signifié'.

According to Coseriu, all periphrases have in common the characteristic semantic integration of their constitutive parts; they are practically the opposite of a compound word. He distinguishes two main forms of periphrasis, (a) lexical and (b) grammatical. The "lexical periphrases" (a) - such as It. tavola calda ('restaurant' or 'lunch menu') or Fr. belle-sœur ('sister-in-law') - exhibit, according to Coseriu, loss of the original meaning of both parts of the periphrasis and the emergence of a new meaning, which cannot be directly derived from the individual constitutive parts (i.e., it has a non-compositional meaning). A tavola calda (literally 'warm table') is neither a table nor something warm; a belle-sœur (literally 'beautiful sister') is not a sister as such and is not necessarily beautiful. On the other hand, in the "grammatical periphrases" (b) (such as Fr. J'ai parlé, Sp. voy a comer, Cat. vaig partir and It. stiamo facendo) the original lexical meaning of one of the constituents is lost (the verbs avoir, ir, anar and stare now serve as auxiliary verbs and no longer mean, respectively, 'to have' (in the sense of 'to possess'), 'to go', 'to go' and 'to stand') while the original lexical meaning of the other constitutive part is preserved (respectively, the verbs 'to speak' (in the participle form), 'to eat' (infinitive), 'to drive' (infinitive) and 'to do' (gerund).

The question has rightly been asked several times ${ }^{23}$ of how to subsume under Coseriu's definition of grammatical periphrases those aspectual constructions

\footnotetext{
"suppletive" and "categorial” verbal periphrases. According to Haspelmath, suppletive periphrases serve as fillers of - primarily synchronically understood - gaps in the syntheticinflectional paradigm (cf. in Latin the modal periphrasis future participle + esse functioning as the future subjunctive). Categorial periphrases, on the other hand, play a more central role in the grammar of a language, since they assume completely the expression of languageparticular grammatical categories.

23 See Squartini's strong objections (1990, 123f.) and the less forceful ones from SchliebenLange (1971) and Dietrich (1973). The latter offers the following definition and problematisation: “'Periphrasis' (and therefore also 'compound', 'circumscription', 'analytical form', 'periphrastic construction', etc.) is generally understood to be a combination of at least two autonomous linguistic units which form a unit in a certain way. It is usually assumed that the elements thus assembled are not on the same level in terms of content, but rather that one or
} 
which native speakers in general intuitively recognise as aspectual verbal periphrases and which also prove to be such in conventional semantic or syntactic tests (see, for example, Gómez Torrego 1988, 127ff.), such as Fr. commencer à parler 'to start talking', Sp. acabar de trabajar 'to have just stopped working', It. continuare a giocare 'to continue playing', Cat. començar a menjar 'to start eating'. On the one hand, these are genuine periphrases, i.e., single-predicate units, as shown in examples (41a-f) and (42a-f), which illustrate the difference between a multi-part predicate unit and several predicate units:

(41a) Sp. Antonio salió corriendo de su despacho.

'Antonio ran out of his office.'

(42a) It. Maria cominciò la lezione parlando di Cesare.

'Maria began the lesson by talking about Cesare.'

Sentences such as (41a) and (42a), which each contain two independent predicate units (respectively, salió and corriendo, and cominciò and parlando), can be easily converted into the following sentences $(41 b-c)$ and $(42 b-c)$ without any syntactic or semantic difficulty:

(41b) Sp. Antonio salió de su despacho y corrió.

'Antonio left his office and ran.'

(41c) Sp. Cuando Antonio salió de su despacho, corría.

'When Antonio left his office, he was running.'

(42b) It. Maria cominciò la lezione e parlò di Cesare.

'Maria began the lesson and talked about Cesare.'

(42c) It. Quando Maria cominciò la lezione, parlava di Cesare.

'When Maria began the lesson, she talked about Cesare.'

In contrast, sentences such as (41d) and (42d), which each contain a multi-part, semantically-related predicate unit, are not semantically equivalent to - hence cannot be paraphrased by - sentences (41e-f) and (42e-f), respectively:

more is subordinate to the other. Non-uniformity, however, consists in assessing the nature and degree of inseparability of these connections, especially in their paradigmatic assignment to other, unassembled linguistic units, in their syntactic use, and, in particular, with regard to their corresponding content, i.e., their semantic configuration.” (Dietrich 1973, 21f., orig. Ger.). 
(41d) Sp. En aquel momento, salió diciendo que era la mujer de su vida.

'At that moment, he came out with it saying she was the woman of his life.'

(41e) Sp. $\neq$ En aquel momento, salió y dijo que era la mujer de su vida. ${ }^{24}$

'At that moment, he came out and said she was the woman of his life.'

(41f) Sp. $\neq$ Cuando salió, dijo que era la mujer de su vida.

'When he came out, he said she was the woman of his life.'

(42d) It. Cominciò a raccontare a tutti che voleva andare a vivere a Londra. 'He started telling everyone he wanted to live in London.'

(42e) It. $\neq$ Cominciò e raccontò a tutti che voleva andare a vivere a Londra. 'He started and told everyone he wanted to live in London.'

(42f) It. $\neq$ Quando cominciò, raccontò a tutti che voleva andare a vivere a Londra.

'When he started, he told everyone he wanted to live in London.'

On the other hand, it cannot be said of constructions such as those in (41d) and (42d) that one of the elements has definitively lost its lexical meaning, for salir and cominciare as auxiliary verbs still display the semantic lexical features found in the full verbs (such as MOVEMENT (to leave) and INGRESSIVENESS (to begin)). However, definitive loss is certainly an essential part of the definition of grammatical periphrasis according to Coseriu (for a more precise explanation of such cases and their classification in the model presented here, see §5.2.2 and §6.2.2). ${ }^{25}$ In this we can see an important, unsolved problem that has led to a more precise definition being frequently adopted in research:

Verbalperiphrasen [sind] eine Verbindung von zwei (oder, in Ausnahmefällen, mehr) Verbalformen, die eine einzige und semantisch einheitliche (nicht-kompositionelle)

24 The not equal sign indicates that sentences (41e and f) and (42e and f) are not the semantic equivalents of, respectively, sentences (41d) and (42d) and not that they are ungrammatical.

25 A definition which reflects the opposite position is given by Olbertz (1998, 32ff.), according to whom multi-part verbal units with auxiliary verbs used exclusively as auxiliary verbs (i.e., which no longer appear also autonomously as full verbs, as lexical units, such as haber/haver in Spanish and Catalan) may not be referred to as verbal periphrases. This would exclude some important analytical constructions (of temporal function) from the category. 
Prädikationseinheit bilden und deren Auxiliarelement bei sehr stark abgeschwächtem semantischen Gehalt als Träger der flexiv markierten Verbalkategorien dient, während ein zweites nicht finites Verbalelement, das also (in den romanischen Sprachen) als Infinitiv, Gerund bzw. Partizip vorliegen kann, die semantische Hauptinformation der Prädikationseinheit beisteuert. (Pusch/Wesch 2003b, 2f.)

Verbal periphrases [are] a combination of two (or, in exceptional cases, more) verbal forms which form a single and semantically uniform (non-compositional) predicate unit and whose auxiliary element serves as a carrier of the inflectionally-marked verbal categories with greatly weakened semantic content, while a second non-finite verbal element, which may therefore appear (in the Romance languages) in the infinitive, gerund or participle, carries the main semantic information of the predicate unit.

However, this definition, too, shows how much the main problem with any attempt at definition lies in the way in which the so-called "loss of meaning" ("desemanticisation" or "semantic bleaching") of one verbal unit of the construction is perceived; in other words, in the way the transformation of a full verb into an auxiliary verb is conceived.

To address this problem, it is necessary to establish parameters to determine the position of a given element on the continuum between analyticity and syntheticity and to measure the stage of grammaticalisation of an auxiliary verb. According to Heine (1993, 54ff.), the linguistic shifts that constitute grammaticalisation form the following four chains or continuums, along which salient stages can be identified: ${ }^{26}$

- desemanticisation: the auxiliary verb loses its original lexical meaning;

- decategorisation: the auxiliary verb loses its morphosyntactic status as a verb;

- cliticisation: the auxiliary verb loses its status as an autonomous word;

- phonological erosion.

However, for several reasons it is difficult to come up with an exact definition of the stages of grammaticalisation from a full verb to an auxiliary verb, and hence also a definition of verbal periphrases. On the one hand, we may ask

26 "Once these schemas are pressed into service for the expression of grammatical concepts, this is likely to trigger a number of linguistic shifts. Some of these shifts will now be looked at in more detail. Each of them can be viewed as constituting a distinct continuum or chain; for the sake of descriptive convenience, however, I will attempt to define a few salient stages or focal points along them. Four chains, each relating to a different aspect of linguistic behavior, will be distinguished referring, respectively, to the semantic (desemanticization), morphosyntactic (decategorialization), morphophonological (cliticization), and phonetic shifts (erosion) concerned.” (Heine 1993, 54). 
whether, in fact, it is always possible to determine at what exact point a (former full) verb begins to take on the characteristics of an auxiliary (i.e., when it becomes more grammatical and less lexical) and when this process is completed, i.e., the point when the lexical-semantic (and syntactic) autonomy of the finite element of a multi-part verbal expression is so weakened that the overall expression may be referred to as periphrastic. ${ }^{27}$ On the other hand, it seems also doubtful whether all of Heine's parameters have the same continual character. Concerning semanticity, is it really possible to detect in all the transformations from a full verb to an auxiliary verb a gradual loss of the lexical meaning of the full verb, or are there examples in which this is not the case and for which other explanations are more appropriate ${ }^{28}$

In order to arrive at a flexible but also satisfactory and comprehensive definition of verbal periphrases from the perspective chosen here, two important specifications need to be added to the overall discussion, one of a more general nature and one more specifically linked to verbal periphrases: a) rather than on stages, the focus should be on parameters, so that grammaticalisation can be reconstructed as a multifactorial process (see also Ch. Lehmann 1995 and 2002); b) it is not the degree of grammaticalisation of an auxiliary verb in a verbal periphrasis that determines the status of a verbal periphrasis as such:

Le perifrasi non sono tutte uguali, non godono tutte allo stesso modo di una certa proprietà, ma si dispongono lungo una scala di perifrasticità con livelli diversi di integrazione. Si va da casi in cui l'integrazione semantica e la desemantizzazione del Hilfsverb sono molto evidenti, a casi in cui Hilfsverb e Hauptverb si mostrano molto più indipendenti. (Squartini 1990, 124)

Periphrases are not all the same, they do not all possess a given property in the same way, rather they lie along a periphrastic scale with different degrees of integration. They range from cases where the semantic integration and the desemanticisation of the Hilfsverb is very evident to cases where the Hilfsverb and Hauptverb are much more independent.

Regardless of the degree of auxiliarisation of one of the parts of the periphrasis, i.e., regardless of how much of the lexical meaning is retained in the auxiliary verb, ${ }^{29}$ or of how strongly grammaticalised it is, or even whether it exists only

27 In this context, see especially Squartini (1998) and Pusch/Wesch (2003b).

28 See Detges' (1999 and 2001) objections to the thesis of desemanticisation (or semantic bleaching). Detges analyses certain cognitive and pragmatic determinants of the grammaticalisation of tense markers in the Romance languages (e.g., aller + infinitive) and shows, in particular, various cases that are not attributable to either metaphor or bleaching, but rather to metonymy (see in particular Detges 1999).

29 Hopper (1991, 22) uses the term "persistence". 
as an auxiliary verb, ${ }^{30}$ all constructions that meet the above criteria to a certain degree are to be defined as periphrases.

\title{
6.3.2 A flexible definition
}

The term verbal periphrasis used in this work is based on the definition given above, which is widely used in research (see the quote from Pusch/Wesch 2003b, 2-3 above), but, on the one hand, it is generalised, and, on the other, it is specified by combining it with the definitional criterion of "scalar periphrasticity” introduced by Squartini (1990 and 1998):

\begin{abstract}
From a synchronic perspective, verbal periphrasis is to be understood as a semantically coherent construction that has the function of a predicate unit and formally consists of two (or more) verbal forms. One of them appears in finite form, performs the function of an auxiliary verb and provides the grammatical and - indirectly proportionally to its degree of auxiliarisation - also a part of the lexical information of the entire construction. The other, which usually ${ }^{31}$ appears in a non-finite form (especially in the infinitive, participle and gerund in the Romance languages), functions as the main verb of the entire construction and contributes directly proportionally to the degree of auxiliarisation of the first element of the periphrasis a more or less large part of the lexical information of the predicate unit.
\end{abstract}

Definition 1: Verbal periphrases

Of course, even if a flexible definition such as Squartini's scalar notion of periphrasticity (1998) is adopted, it is still not easy to determine the degree of grammaticality that an aspectual verbal periphrasis has reached or the extent of the lexical meaning it retains. However, this statement no longer seems relevant, as the scalar notion of periphrasticity is, by definition, not required to provide a classification of precisely delimited - i.e., discrete - units in terms of degree of grammaticality. This definition, therefore, makes it possible to classify together synchronously all constructions that are perceived as aspectual verbal

30 This would allow us to also categorise constructions such as those with haber/haver in Spanish and Catalan as verbal periphrases (see footnote 25 in this chapter).

31 A problematic aspect of the common definition of periphrasis (see, among others, Gómez Torrego 1988) is the prerequisite that these multi-part expressions must consist of an inflected and at least one uninflected form. However, it is well-known - both from general language typological research and comparative Romance studies - that serially coordinated constructions with several inflected verbal elements can also have periphrastic status (in this case, an auxiliary can usually be clearly identified as such); see Pusch (2003b) and Pusch/Wesch (2003b). 
periphrases, i.e., both highly grammaticalised and weakly grammaticalised constructions, as presented in the following Romance examples:

(43) It. Leo sta [Pres.] guardando un episodio di Shaun the Sheep. [stare + Ger.] 'Leo is watching an episode of Shaun the Sheep.'

(44) It. Julia va [Pres.] raccontando storie bizzarre da tre settimane. [andare + Ger.] 'Julia has been going around telling odd stories for three weeks.'

(45) It. Leo finisce [Pres.] di mangiare la pasta. [ [ finire di + Inf.] 'Leo is finishing eating his pasta.'

(46) Fr. Julie est [Prés.] en train de préparer le repas. [être en train de + Inf.] 'Julie is preparing the meal.'

(47) Fr. Julie vient [Prés.] de chanter. [venir de + Inf.] 'Julie has just sung.'

(48) Fr. Marie-Rose se met [Prés.] à chanter. [se mettre à + Inf.] 'Marie-Rose is starting to sing.'

(49) Sp. Clara está [Pres.] hablando de los hombres de su vida. [estar + Ger.] 'Clara is talking about the men in her life.'

(50) Sp. Juan anda [Pres.] pensando en cómo arreglar el problema. [andar + Ger.] 'Juan is thinking about how to solve the problem.'

(51) Sp. Termino [Pres.] de trabajar a las tres. [terminar de + Inf.] 'I finish working at three o'clock.'

(52) Cat. M'estic [Pres.] menjant una galeta. [estar + Ger.] 'I'm eating a biscuit.'

(53) Cat. Acabo [Pres.] de parlar amb el president de la república italiana. [acabar de + Inf.] 'I have just spoken with the President of the Italian Republic.'

(54) Cat. El pacient ara tot just comença [Pres.] a tastar aliment sòlid. [començar a + Inf.] 'The patient is just beginning to eat solid food.' 
All the two-part constructions in (43)-(54) are perceived by native speakers as belonging together syntactically and semantically as predicate units. However, periphrases such as It. stare + gerund (43), Fr. être en train de + infinitive (46), Sp. estar + gerund (49) and Cat. estar + gerund (52) have a greater degree of grammaticality (and are therefore closer to inflectionally-marked forms of an aspectual nature) than periphrases of the type It. finire di + infinitive (45), Fr. se mettre $\grave{a}+$ infinitive (48), Sp. terminar de + infinitive (51) and Cat. començar $a+$ infinitive $(54),{ }^{32}$ for the lexical meaning of the first verbal element ${ }^{33}$ in the constructions in (43), (49) and (52) is very weakened (it has nothing to do with 'to exist' or 'to remain' and consequently these meanings do not merge with the overall meaning of the construction), so that they contribute almost exclusively grammatical information and hardly any lexical semantic information to the predicate unit as a whole. The main lexical semantic information is provided by the second element in the construction, respectively, 'to watch', 'to talk' and 'to eat'. In contrast, the first element in the constructions in (45), (48), (51) and (54) contributes a certain degree of lexical meaning to that of the predicate unit as a whole: given the overall meaning of the periphrases, we can see that the meaning of 'to finish' is retained in the last stages of eating in (45), that of 'to begin' in the first stages of eating in (54). The fact that the first element in the constructions is to a certain degree still an auxiliary verb with a grammatical function and is not a main (or full) verb seems evident, if, for example, the construction in (45) is compared with example (55), where finire is clearly in its function as a main verb (with a distinctly lexical meaning, which is 'to spend' here, that is 'to finish' his money): ${ }^{34}$

(55) It. Ogni volta che va in pasticceria Leo finisce [Pres.] tutti i soldini messi da parte mangiando tortine al cioccolato.

'Every time he goes to the bakery Leo spends all his saved money eating chocolate cakes.'

32 The periphrastic constructions in examples (45), (48), (51) and (54) are at an intermediate stage on the grammaticalisation scale, where se mettre $\grave{a}+$ infinitive has a higher degree of grammaticality than the other three periphrases.

33 In the case of French, it is rather a so-called prepositional periphrasis.

34 For this purpose, the test used in $§ 6.3 .1$ can also be applied here: while Ogni volta che va in pasticceria Leo finisce tutti i soldini messi da parte mangiando tortine al cioccolato could be easily paraphrased by Ogni volta che va in pasticceria Leo finisce tutti i soldini e mangia tortine al cioccolato or Quando Leo va in pasticceria mangia tortine al cioccolato e finisce tutti $i$ soldini messi da parte, the sentences $\neq$ Leo finisce e mangia la pasta and $\neq Q$ uando Leo finisce mangia la pasta cannot be regarded as paraphrases of Leo finisce di mangiare la pasta. 


\subsubsection{STARE + gerund - a semasiological parenthesis}

The more highly grammaticalised Romance aspectual verbal periphrases of the type STARE + gerund will now be dealt with in more detail. However, an important issue from a semasiological perspective - i.e., with regard to the form in question and its function in different contexts - must first be clarified in order to arrive at the various aspectual meanings expressed in each case. Consider the following examples:

(56) It. Mi scusi, sto [Pres.] telefonando da lontano e devo riattaccare. [stare + Ger.] 'I'm sorry, I'm calling from far away and I have to hang up.'

(57) It. Ho perso le chiavi per la terza volta in un'ora: è segno che sto [Pres.] impazzendo. [stare + Ger.]

'I have lost my keys for the third time in an hour: it's a sign that I'm going crazy.'

(58) Sp. Julia estaba [Imp.] escribiendo una carta cuando Leo entró en su habitación. [estar + Ger.]

'Julia was writing a letter when Leo came into her room.'

(59) Sp. ¡No sabes lo que estoy [Pres.] soportando con esta mujer! [estar + Ger.] 'You don't know what I'm going through with this woman!'

Although the same analytical forms are used in (56) and (57) and in (58) and (59), i.e., they contain the same formal type of verbal periphrasis, they do not have the same aspectual content. One of the typical uses of Romance periphrases of the type STARE + gerund is to express aspectual contents that can be called "progressive-focalised" after Bertinetto (1995a), and these are exemplified in (56), (57) and (58). ${ }^{35}$ This type of aspectual content - or, in the

35 Bertinetto (1995a) distinguishes between two types of progressive and compares them in detail: the first type is called Progressif Focalisé (Prog. Foc.), the second Progressif Duratif (Prog. Dur.). While the Prog. Foc. refers to a single moment of focus, which is particularly emphasised and considered, and which "simply indicates a moment in the unfolding of the event, while the actual duration of the event remains undetermined" (Bertinetto 1995a, 39, orig. Fr.), the Prog. Dur. determines the aspectual value of the state of affairs in relation to an interval (a longer interval, which thus represents duration) (see also Bertinetto 1986 in general on the progressive). It is interesting to compare this with Coseriu's interpretation of the STARE + gerund periphrasis. In a case like sto facendo (a construction that, according to Bertinetto, expresses a Prog. Foc.), which expresses both a kontinuative Phase ('continuous stage') and a 
terminology used here, this combination of aspectual basic conceptualisations can be described in summary form as follows (for a more precise classification of these cases in the model developed here see §6.2.2):

- The state of affairs is presented as externally non-delimited (EA/nd) and is therefore considered open with regard to its (initial and) final delimitation (and therefore overall as uncompleted). In (56), when the telephone call started and when it will end is not stated; likewise in (58) there is no information as to when Julia started writing the letter and when she will end it.

- The state of affairs is internally subdivided (IA/s) and therefore comprises several points in time $t_{\mathrm{x} 1}, \mathrm{t}_{\mathrm{x} 2}, \ldots \mathrm{t}_{\mathrm{xn}}$, but is considered in its unfolding from a certain point in time $t_{x}$, i.e., a certain $t_{x}$ (with regard to the internal aspectual subdivision of the situation frame) is focussed. The ongoing telephone conversation in (56) and the writing of the letter in (58) are considered from a specifically chosen moment of, respectively, telephoning $t_{x 1}$ and writing $t_{x 2}$.

However, periphrases of the type STARE + gerund ${ }^{36}$ are polysemous, or rather polyfunctional linguistic forms, that can therefore express several aspectual contents. Cases can also be found in which verbal periphrases of this type express a progressive-durative content (see Bertinetto 1995a). In (57) and (59), for example, the following aspectual structuring of the state of affairs can be observed:

- The state of affairs - as in (56) and (58) - is presented as open with regard to its (beginning and) end, so it is considered as not externally delimited (EA/ nd) and therefore not completed. When my going crazy in (57) or my going through with this woman in (59) began and will end are not indicated.

- The state of affairs - as in (56) and (58) - is presented as internally subdivided (IA/s). However, in (57) and (59) it is not considered from a certain, focussed point of time $t_{x}$, but as a continuing process. This means that no specific moment within the situation frame is highlighted, but rather that all the individual $\mathrm{t}_{\mathrm{x} 1}, \mathrm{t}_{\mathrm{x} 2}, \ldots \mathrm{t}_{\mathrm{xn}}$ of the internal aspectuality of this state of affairs (except, of course, the initial and final delimitation of the state of affairs itself) are focussed. In (57), the form sto impazzendo expresses a

\footnotetext{
partialisierende Schau ('partialising view'), Coseriu (1976) speaks of syncretism between Phase and Schau: periphrases, which mainly represent a partialisierende Schau, can take on further meaning, namely that which represents the degree of the process. Sto facendo focusses (even though it expresses a kontinuative Phase) a fixed (temporal) point from which the process that continues developing (in this precise moment) is observed.

36 What is meant here, of course, is the respective realisations of this type in Italian and Spanish, but a similar statement could also apply to Catalan.
} 
graduality that is observed not in a certain moment of craziness, but in various moments of this craziness (hence the aforementioned durativity), in which, moreover, the craziness gradually increases over several points in time (for further details see §6.2.2.8, where the role AA plays here is described); similarly, in (59) several moments $t_{x 1}, t_{x 2}, \ldots t_{x n}$ of my going through with this woman, i.e., a period of time, are foregrounded in the state of affairs.

Cases like (57) and (59), however, are in the minority in Italian, as is shown in more detail below. Their use is highly restricted to certain aspectual contexts, which are found in clearly lower frequencies than those in (56) (externally nondelimited (EA/nd), internally subdivided (IA/s) and with a focus on one of the $t_{x}$ of the internal aspectuality). This highlights one of the most important differences between the various Romance languages regarding the use of this type of periphrasis, because in Spanish and Catalan - as will be shown in the following section - this so-called durative use is highly frequent.

\subsubsection{STARE + gerund - contexts of use}

In contemporary Spanish and Catalan, the possibilities of expressing morphologically different types or realisations of external aspectuality (referred to in Chapter 4 as (EA/d) and (EA/nd)) through periphrases of the type STARE + gerund - which is, by the way, also formally identical - are very similar. This is illustrated by the possible and impossible variants in the comparative examples $(60 a-d)$ and $(61 a-d)$ :

(60a) Sp. Leo está [Pres.] comiendo con Julia.

'Leo is eating with Julia.'

(60b) Sp. Leo ha estado [Perf. Com.] comiendo con Julia esta tarde. 'Leo has been eating with Julia this afternoon.'

(60c) Sp. Leo estaba [Imp.] comiendo con Julia, cuando Juan salió de su casa. 'Leo was eating with Julia, when Juan left his house.'

(60d) Sp. Leo estuvo [Perf. Sim.] comiendo con Julia toda la tarde. 'Leo was eating with Julia all afternoon.'

(61a) Cat. El Leo está [Pres.] menjant amb la Júlia. 'Leo is eating with Julia.' 
(61b) Cat. El Leo avui ha menjat [Pret. Indef.] amb la Júlia. 'Leo ate with Julia today.'

(61c) Cat. El Leo estava [Imp.] menjant amb la Júlia, quand van trucar a la porta. 'Leo was eating with Julia, when someone knocked at the door.'

(61d) Cat. El Leo estiguà [Pret. Perf. Sim.]/va estar [Pret. Perf. Per.] menjant amb la Júlia durant dos dies.

'Leo was eating with Julia for two days.'

The use of the Sp./Cat. periphrasis estar + gerund in states of affairs with external aspectuality of the type non-delimited (EA/nd) is unproblematic. In (60a and c), and in (61a and c), in which the auxiliary verb appears respectively in each pair in the present and imperfect tense, neither the initial nor the final moment of Leo's and Julia's eating is focussed; the pluriphasic state of affairs is represented in its progression - and from a particular $t_{x}$ in this progression. However, the construction can also appear in states of affairs with external aspectuality of the type delimited (EA/d), as in examples (60b and d) and in (61b and d) (see also the analyses in §§6.2.2.9-6.2.2.12). Here, the initial and the final moment of Leo's and Julia's eating are focussed, so the state of affairs is represented as completed, i.e., as delimited within a particular period of time: Leo and Julia ate together for a limited time, i.e., until the present moment of speaking in (60b), a whole afternoon in (60d) and for two days in (61d). This is the case even though the individual moments of the progression of the pluriphasic state of affairs within this delimited period of time are further focussed (i.e., all and every single one, as shown above for (57) and (59)), so that within the given external boundaries of the states of affairs the internal constitutive moments are represented as being in progress: in all the examples all the single $t_{x 1}, t_{x 2}, \ldots t_{x n}$ of Leo's and Julia's eating together are further focussed.

The auxiliary verb, moreover, carries morphological markers of an analytical nature (the Pretérito Perfecto Compuesto and the Pretèrit Indefinit Indicatiu in (60b) and (61b), respectively) and a synthetic nature (the Pretérito Indefinido and the Pretèrit Perfet Simple in (60d) and (61d), respectively). In both languages, estar + gerund can have either a progressive-durative function (this is the case, e.g., in combination with morphological markers on the auxiliary verb which express EA/d, as in (60b and d) and (61b and d), though not exclusively), or a progressive-focalised function (as in (60a and c) and (61a and c)), so the periphrasis is not just specified for one of the aspectual meanings. Examples (62)-(64), which illustrate the progressive-durative use, further confirm this: 
(62) Sp. Yo salgo de aquí a las seis y media de la mañana y me estoy trabajando hasta las doce, la una de la mañana.

'I leave here at 6:30 in the morning and I'm working until twelve, one o'clock in the morning.'

(example and translation taken from Squartini 1998, 77)

(63) Sp. Estuvo escribiendo hasta después del alba.

'He was writing until after dawn.'

(example and translation taken from Squartini 1998, 38)

(64) Sp. No me mire así, no piense que durante todo este tiempo me he estado burlando de su inocencia y de su voluntad de saber.

'Don't look at me in that way. Don't think that for all this time I have been mocking her innocence and her desire to know.'

(example and translation taken from Squartini 1998, 39)

The aspectual possibilities of these periphrases are interpreted differently by Laca (1995), who insists on the exclusive imperfective nature of the construction, which, therefore, even in combination with perfective tenses, continues to convey an imperfective aspectual meaning (or in the terminology used here, $\mathrm{EA} / \mathrm{nd})$ :

Cette particularité combinatoire [avec les temps perfectifs sds] ne contredit cependant en rien le caractère aspectuel imperfectif de la périphrase. En effet, on s'accorde à considérer comme imperfective toute forme verbale qui exclut la visualisation de la 'borne droite' d'une situation. [...] Les analogies constatées [entre l'imparfait et estar + Gérondif sds] constituent des indices à mon avis très clairs en faveur de la nature aspectuelle imperfective de cette périphrase, qui est maintenue même dans sa combinaison avec les temps perfectifs. (Laca 1995, 496-498)

However, this particular type of combination [with the perfective tenses sds] does not contradict in any way the imperfective aspectual nature of the periphrasis. Indeed, we agree to consider any verbal form where the 'right boundary' of the situation is not visible as imperfective. [...] The analogies observed [between the imperfect and estar + gerund sds] are, in my opinion, very clear indications of the imperfective aspectual nature of this periphrasis, which is maintained even when it is combined with perfective tenses.

Laca makes a comparison of imperfect and telic verbs to show the analogy between the imperfect and the aforementioned verbal periphrasis, and of the behaviour of the periphrasis in combination with the imperfect and with telic verbs to prove the thesis advocated above. One problematic aspect, 
however, is that (non-)telicity and (im-)perfectivity are thus mixed (see §2.5 on the objection to mixing aspectual-grammatical and actional categories voiced by advocates of bidimensional approaches). If these categories are not identical by definition, it may also not be sufficient to show the nontelicity of a verb (or the so-called "suspension of the telos" in a state of affairs) to prove the imperfectivity of a state of affairs (or even a construction per se). ${ }^{37}$

However, the theoretical direction associated with the bidimensionalist tradition - see Gómez Torrego (1988), for example - also offers an interpretation of the aspectual contents of this periphrasis, which provides for the possibility that STARE + gerund has no particular aspectual nature, but can express various aspectual meanings:

[...] hemos puesto ejemplos con el auxiliar en presente o pretérito imperfecto, formas muy apropiadas para la descripción por su carácter imperfectivo, en consonancia, también, con el valor imperfectivo del gerundio. Si el auxiliar apareciera en pretéritos indefinidos o pretéritos perfectos compuestos, entonces se conjuntan el valor imperfectivo del gerundio con el perfectivo del auxiliar. De esta forma, se nos ofrece una imagen o idea durativa que se da por acabada en un momento determinado: Estuve estudiando toda la noche. (Gómez Torrego 1988, 141, my underlying, sds)

[...] we have given examples with the auxiliary in the presente or preterito imperfecto that are highly appropriate forms for describing its imperfective nature, in accordance, also, with the imperfective value of the gerund. If the auxiliary appears in the preteritos indefinidos or pretéritos perfectos compuestos, then the imperfective value of the gerund is combined with the perfective value of the auxiliary. In this way, we are offered a durative image or idea that is considered to be finished at a given time: I was studying all night.

The Ibero-Romance use of STARE + gerund, which can also express external aspectuality of the type delimited (EA/d), differs significantly from use of the same formal means in other (including Romance) languages, which do not have the same means to express this particular combination of aspectual building blocks. Contemporary Italian is clearly different from Spanish and

37 The tests used by Laca $(1995,497)$ are a little problematic. She compares the following examples: (a) \#Es va morir, però a la fin no es va morir; (b) Es moria, però a la fin no es va morir; (c) \#Ahir vaig corregir els exercicis, però no vaig acabar de corregir-los; (d) Ahir vaig estar corregint els exercicis, però no vaig acabar de corregir-los, although the forms in (c) and (d) are not exactly comparable to those in (a) and (b). For a precise comparison, the following forms should be cited: (e) \#Ahir vaig corregir els exercicis, però no vaig corregir-los; (f) \#Ahir vaig estar corregint els exercicis, però no vaig corregir-los. In this case, it can be seen that there is no analogy between (b) and (f) that would justify the syllogism in the interpretation of them. 
Catalan in its use of the periphrasis STARE + gerund. ${ }^{38}$ In terms of the restrictions of use and compatibility, it is more similar to the French periphrasis être en train de + infinitive (although this construction has a completely different formal origin). ${ }^{39}$

In fact, contemporary Italian and French progressive constructions can only be combined with a) synthetic tenses that have b) non-delimited external aspectuality (EA/nd) and c) are specialised for the so-called "focalised progressivity". This is clearly shown in the possible and impossible variants of the comparative examples $(65 a-d)$ and $(66 a-d)$ :

(65a) It. Leo sta [Pres.] mangiando con Julia. (EA/nd)

'Leo is eating with Julia.'

(65b) It. *Leo è stato [Perf. Com.] mangiando con Julia.

'Leo has been eating with Julia.'

(65c) It. Leo stava [Imp.] mangiando con Julia. (EA/nd)

'Leo was eating with Julia.'

(65d) It. ^Leo stette [Perf. Sem.] mangiando con Julia.

'Leo was eating with Julia.'

(66a) Fr. Léo est [Prés.] en train de manger avec Julie. (EA/nd)

'Leo is eating with Julie.'

(66b) Fr. *Léo a été [Pass. Com.] en train de manger avec Julie.

'Leo has been eating with Julie.'

38 More recent literature on the conditions of use and characteristics of this periphrasis in Italian includes, among others, Brianti (1992 and 2000), Streb (2002), Natale (2009) and Dessì Schmid (2011b). For the classic literature on the subject, see below.

39 The prepositional periphrasis être en train de + infinitive is the most recent of the French aspectual progressive (copulative) periphrases. At the beginning of its grammaticalisation in the 17th and 18th centuries it was used as a modal periphrasis expressing the subject's intention (mood) to do something, see Gougenheim $(1929,63)$; it became common as a progressive aspectual periphrasis around the middle of the 19th century, although, of course, examples of its use with this function can also be found earlier. For general information on the French periphrasis être en train de + infinitive, see, among others, Gougenheim (1929), Laca (2004a), Mitko (1999), Pusch (2003a), Squartini (1998) and Werner (1980). 
(66c) Fr. Léo était [Imp.] en train de manger avec Julie. (EA/nd)

'Leo was eating with Julie.'

(66d) Fr. *Léo fut [Pass. Sim.] en train de manger avec Julie.

'Leo was eating with Julie.'

In other words, it is impossible for Italian and French to express states of affairs with external aspectuality of the type delimited (EA/d) with the verbal periphrasis stare + gerund or être en train de + infinitive. Furthermore, in these languages - as mentioned in $§ 6.3 .3$ - their use with a progressive-durative function is rare.

A diachronic examination of this construction in Italian that follows the path of its grammaticalisation can help us understand the reasons for its restrictions and aspectual specialisations.

\subsubsection{STARE + gerund in Italian - the grammaticalisation path}

So far, the phenomenon of verbal periphrasis has mainly been described and defined synchronically, but now we ask what path does the grammaticalisation of the first element of the construction follow? What happens when aspectual periphrastic constructions emerge?

From a diachronic perspective, verbal periphrases are the outcome of grammaticalisation processes, i.e., the result of a change from independent lexical units to more or less grammatical units (see what was said in $§ 6.3 .1$ regarding auxiliary verbs). ${ }^{40}$ Aspectual verbal periphrases in particular would then, of course, also have to be understood as the outcome of grammaticalisation processes, namely, as the result of a change from a lexically expressed verb meaning or verb meaning component to another, but somehow cognitively connected, grammatically expressed aspectual verb meaning (component). From this perspective and on the basis of results from grammaticalisation research in general in recent years, lexicon and grammar can only be considered as two ends of a continuum (see §2.4.2 for more details). We cannot, therefore, help but assume that concepts such as periphrasticity and auxiliarity are also scalar, in agreement with Squartini (1990 and 1998), which has already become clear from the above analysis of the phenomenon from a synchronic

40 On grammaticalisation research in general see, among others, Ch. Lehmann (1995), Hopper/Traugott (2003) and Detges/Waltereit (2002); on the grammaticalisation of auxiliaries see Heine (1993); on the issue of grammaticalisation in general see Chapters 2 and 3 here. 
perspective. If we are looking for indications of grammaticalisation, they can be found in their frequency of use, because:

Textual frequency is often considered prima facie evidence of degree of grammaticalization. (Hopper/Traugott 2003, 113) ${ }^{41}$

Consistent with Hopper and Traugott's claim, ${ }^{42}$ an indirect indication of the grammaticalisation of the Italian stare + gerund in its so-called progressivefocalised use can certainly be found in the huge increase in its frequency in both literary and newspaper language since the last century (see Durante 1981 as well as Squartini 1990 and 1998, Bertinetto 1996 and Del Pietro 1995). ${ }^{43}$

Different opinions can be found on the stage of grammaticalisation reached by the progressive periphrasis in Italian ranging between two extremes. On the one hand, Marchand (1955) denies that it has any grammaticality and banishes it to the level of stylistics, while on the other hand, Blücher (1973 and 1974) equates it with the developmental stage of the English continuous form. The majority of more recent research on the progressive (Bertinetto 1986 and 1995b) holds that It. stare + gerund cannot simply be attributed a stylistic function, but rather a grammatical ${ }^{44}$ one, albeit not the same one it has taken on in English.

Sprachen unterscheiden sich hauptsächlich in dem, was sie ausdrücken müssen, und nicht so sehr in dem, was sie ausdrücken können. (Jakobson 1981 [1959], 195)

Languages differ mainly in what they must express and not so much in what they can express.

41 In this context, see also Heine/Claudi/Hünnemeyer (1991) and Bybee/Perkins/Pagliuca (1994).

42 In this context, see also Squartini $(1998,87)$ : "When stare becomes a specialized marker of progressive aspect it strengthens its position in the verb system, becoming more grammaticalized, and therefore increases its frequency with respect to the other gerundial periphrases.”

43 This is not the place to discuss the reasons for this increase, but it should be noted that Durante's (1981) thesis that it was due to the influence of English on Italian seems unlikely. It is more likely to be due to the gradual spread of a spoken national language than to English influence. See also Squartini's (1998, 86-87) analysis of oral and written corpora, which points to a far more frequent occurrence of stare + gerund in the oral language.

44 On the basis of Heine's criteria (1993), which can be used to measure the grammaticalisation stages of an auxiliary verb (see §6.3.1), it can be said that the progressive periphrasis is grammaticalised to a quite high degree in Italian, because not only has the first stage of desemanticisation been reached, i.e., loss of the lexical meaning of stare, but also the second, since there is a clear sign of at least partial decategorisation in its incompatibility with morphemes that (normally) express external aspectuality of the type delimited, i.e., its morphological paradigm has shrunk to the imperfective forms. 
If we consider this famous phrase of Jakobson's, we find something important that speaks against Blücher's position: the obligatoriness of the continuous form in English has no equivalent in Italian - nor in Spanish, Catalan or French.

However, as the theoretical emphasis here was placed rather on the semantic development, it is the grammaticalisation path of It. stare + gerund that I mainly wish to investigate. For this purpose, the following examples from older language stages of Italian need to be analysed in more detail:

(67) It. Le notti e le dia sta [Pres.] plorando. (Elegia giudeo-italiana, 12th-13th c., from Durante 1981, 180) 'He is crying night and day.'

(68) It. Pigliava al far del giorno alcun riposo/sempre sognando stava [Imp.] in quel desire. (Boiardo, Orlando Innamorato, 15th c., from Dietrich 1985, 204)

'At break of day he took some rest/still dreaming he was in that desire.’

(69) It. E mentre che lui stava [Imp.] riguardando,/quello altro campion con voce altiera/gli disse. (Boiardo, Orlando Innamorato, 15th c.)

'And while he was looking, the other hero in a haughty voice said to him.'

(example and translation taken from Squartini 1998, 85)

(70) It. Sono stato [Perf. Com.] un poco pensando meco. (Aretino, Talanta, 16th c., from Durante 1981, 180)

'I have been thinking a little bit by myself.'

(71) It. Dopo queste e altre simili parole, il conte Attilio uscì, per andare a caccia; e don Rodrigo stette [Perf. Sem.] aspettando con ansietà il ritorno del Griso. (Manzoni, I promessi sposi, 1840-42, from Squartini 1990, 193) 'After these and other similar words, Count Attilio went out to hunt; and Don Rodrigo was waiting anxiously for the return of Griso.'

In Old Italian and until the 19th century, stare + gerund was compatible both with forms that express aspectuality of the type externally non-delimited (EA/nd) (in (69) with the auxiliary verb in the Imperfetto) and with forms that express aspectuality of the type externally delimited (EA/d) (as can be clearly seen in (70) and (71), where the auxiliary verb is in the Passato Prossimo and Passato 
Remoto, respectively). Stare + gerund was also found - evenly distributed - in both progressive-focalised (as in (69)) and progressive-durative use (as in (67) and (68)). ${ }^{45}$

If we compare the use of this construction in this language stage with its use in contemporary Italian, we can note the following changes:

- a significant increase in the use of the periphrasis in its progressivefocalised meaning and a decrease in its durative use;

- a reduction in its morphological combinatorics, in particular a reduction in its compatibility with morphemes, expressing aspectuality of the type externally delimited $(\mathrm{EA} / \mathrm{d}) .^{46}$

The semantic grammaticalisation path of the Italian progressive periphrasis as could be claimed with Squartini $(1998,73 \mathrm{ff}$.) - is one that has led from LOCATIVITY via DURATIVITY to IMPERFECTIVE PROGRESSIVITY. ${ }^{47}$ It thus proceeds entirely in the sense of the - albeit not absolutely universal, but at least crosslinguistic - processes described by Bybee/Dahl (1989) and Bybee/Perkins/ Pagliuca (1994):

\section{LOCATIVITY > DURATIVITY > IMPERFECTIVE PROGRESSIVITY}

Grammaticalisation path of stare + gerund in Italian I.

More precisely, Squartini's (1998) detailed study of the aspectual meaning components of the verbs that participate in periphrastic constructions shows that this process of grammaticalisation from LOCATIVITY (via DURATIVITY) to IMPERFECTIVE PROGRESSIVITY mirrors the development of an originally "actional” - Squartini's terminology must be used here - to an aspectual-grammatically driven form. The earlier durative use of the Italian periphrasis stare + gerund was only possible with non-telic Aktionsarten verbs (according to Vendler's classification of actional classes (1957), these are “activities”, see \$1.2.4), although it could have both imperfective and perfective aspect. Today's progressive periphrasis is compatible

45 Concerning stare + gerund in Old Italian, see also Ferreri (1983) and Heinemann (2003). 46 See, among others, Durante (1981), Bertinetto (1986) and Squartini (1990, 1998). This reduction, however, applies to both the indicative and subjunctive modes, as shown in the following examples, in which stava expresses only externally delimited aspectuality in the indicative and stesse only in the subjunctive: Gli chiesi se stava ancora lavorando a Roma or Non sapevo se stesse lavorando alla sua tesi o se avesse terminato.

47 See Bertinetto (1995a) for a presentation of the typology of the diachronic development of progressive constructions and actional constraints (verb types allowed in progressive constructions). 
with almost all Aktionsarten, but can only have imperfective aspect. In a further grammaticalisation step towards progressivity, stare + gerund was also used in so-called telic contexts (especially with "accomplishments" and "achievements" in Vendler’s sense). In Squartini’s bidimensional approach (see §2.4), the use of progressive periphrases in combination with telic verbs is a means of indicating suspension of the endpoint to be reached. According to Squartini, this becomes evident in examples such as (72), which may be analysed as follows: the endpoint of the state of affairs conveyed by the verb stem of scrivere in combination with the argument una lettera, i.e., the finishing of the letter, is cancelled or blocked by the insertion of stava finendo and therefore not reached. ${ }^{48}$ In the very moment (emphasised by giusto) when Julia called, Francesca was writing the letter which thus was not finished: ${ }^{49}$

(72) It. Francesca stava [Imp.] giusto finendo di scrivere una lettera, quando ha telefonato Julia. [stare + Ger.]

'Francesca was just finishing writing a letter when Julia called.'

Therefore, Schema (1) ought to be specified for Italian as in Schema (2) (following Squartini 1998, 73ff.):

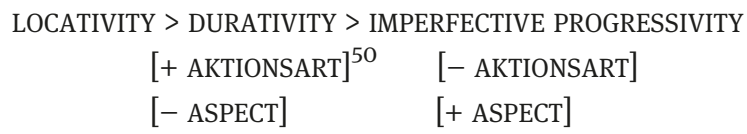

Schema 2: Grammaticalisation path of stare + gerund in Italian II.

48 This analysis naturally presupposes that the verb is considered irrespective of the concrete state of affairs in which it appears, i.e., irrespective of its combination with the other elements in the sentence in question and the meaning it thereby assumes there.

49 Sasse (1991) describes these as typical grammaticalisation paths of aspectual-grammatical markers. Squartini's (1990) and Bertinetto's (1996) data show accomplishments increasing in parallel with an increase in use of the periphrasis to express the progressive. It has already been mentioned (see footnote 39) that the French verbal periphrasis être en train de + infinitive has a different origin to that of the corresponding periphrasis in Italian, and its grammaticalisation path is, of course, likewise different: "[...] even though the French construction ends up performing the function of progressive marker, just like the Italian stare periphrasis, it has a different history. Its progressive meaning has a different origin, deriving from the modal sense of intention and volition, and does not pass through a durative stage. [...] The French form, which is created with different semantic tools, has a completely different path of grammaticalization [...].” (Squartini 1998, 127).

50 Squartini speaks of "actionality" for what is commonly referred to as Aktionsart. 
So far, our discussion of aspectual verbal periphrases has implied a general aspectual content common to all verbal periphrases. Now, however, we can see that in Squartini's analysis - where this is also implied - this commonality is again split into aspect and Aktionsart. We are therefore dealing again with the well-known problem of the semantic subdivision of the aspectual domain, which is, however, particularly problematic in phenomena such as verbal periphrases, as will be shown in more detail in the following section.

\subsection{4 "Aspectual-grammatical" and "actional" verbal periphrases?}

On the one hand, Squartini emphasises that it is indeed the progressive that is particularly useful for showing how the relationship between Aktionsart and aspect can be interpreted as a diachronic process. It is, in his view, precisely this emergence of aspect from Aktionsart that makes it possible to recognise the semantic similarity of the two categories, since they derive from the same "cognitive mould":

\footnotetext{
It [the progressive sds] is rather to be conceived as an aspectual form, which derives diachronically (at least in some languages) from a construction constrained to a given actional value. From this point of view, even if aspect and actionality have to be considered as independent notions, a diachronic relationship between the two can be assumed, so that aspect emerges from actionality, or, put another way, aspect derives from the grammaticalization of actionality. This is why a semantic similarity between aspect and actionality can be recognized, [...] for aspect emerges from the same cognitive mould as actionality. (Squartini 1998, 17f.)
}

On the other hand, he insists on maintaining the distinction between aspect and Aktionsart, which should not be confounded on the synchronic level. Yet, it seems more reasonable to deal with the problem not by distinguishing diachrony and synchrony, but rather by distinguishing onomasiological and semasiological procedures.

Insisting on the categorial distinction, Squartini agrees with the two classic objections against unidimensional approaches (see also §2.5). The first is that the differences connected with language levels and with conceptual and categorial subdivisions are levelled out. In other words, he is mainly concerned with positioning himself against the customary identification of the subcategories aspect and Aktionsart; for example, against equating imperfectivity with durativity and perfectivity with telicity. This is a confusion which, in his opinion, does not allow for the type of subtle investigation of the developments and states of phenomena that he undertakes in his work. The second objection 
concerns the unsuitability of these approaches for highly detailed investigation and analysis of concrete linguistic phenomena.

However, insisting on the distinction between aspect and Aktionsart entails once again some major difficulties.

First of all, it is not easy to identify a cognitive, categorial source with contents common to both on the diachronic level and at the same time to insist on a semantic - i.e., not only formal, morphological - categorial distinction on the synchronic level, as synchronic polyfunctionality is only a kind of snapshot of functional change in diachrony. ${ }^{51}$ What, then, is the common ground on the basis of which - and this seems to be a particularly big problem - we can call all aspectual periphrases - from the highest to the lowest degree of periphrasticity - aspectual, if this common semantic basis is missing in synchrony? How are we to assign examples such as those discussed at the beginning, i.e., the low-grammaticalised or actional- (Aktionsart-) driven periphrases such as It. cominciare a parlare, Fr. se mettre à chanter, Sp. andar pensando, Cat. acabar de parlar? Are they to be conceived as Aktionsart or aspect? Should we rather talk about actional periphrases? And if so, when do they become genuine aspectual-grammatical ${ }^{52}$ periphrases? Finally, we can also ask why, with regard to elements in transition, we should operate with discrete semantic categories, especially when we can clearly identify their cognitive - semantic - unity, even if this consists only in a common origin (the "same cognitive mould" mentioned above)?

With regard to the first criticism of unidimensionality, the following needs to be repeated: ${ }^{53}$ if we posit the existence of two categories which are also semantically different and are expressed on two different linguistic levels (grammar and lexicon), it is theoretically less consistent and can lead to confusions of various kinds if we then define subcategories such as imperfective and perfective on the one hand and stative, durative, telic, etc. on the other and subsequently identify these subcategories with each other again, for example, the imperfective with the durative or the perfective with the telic. It goes without saying that these subcategories of the aspectual domain are, by definition, conceived differently and therefore cannot simply be identified with each other. But it is equally clear that the similarities, the semantic affinities which, on the one hand, relate telicity to perfectivity, and, on the other hand, atelicity to imperfectivity, are already intuitively

51 See the relationship between polysemy and semantic change in the lexicon.

52 Here, I use the term "aspectual-grammatical” (Ger. aspektuell) - and not "aspectual” (Ger. aspektual) as is usual in the conception of this model - since this passage refers to the traditionally understood category of aspect (as opposed to that of Aktionsart, cf. "actional" above). 53 In this context, see also Chapters 2 and 3. 
obvious. But is it really necessary - and this question needs to be repeated here to assume at first the existence of two categories, only to have to then reunite them?

It is perfectly legitimate and practical to adhere to such distinctions when working semasiologically (both synchronically and diachronically), but when working onomasiologically and acknowledging that we are dealing with the same "cognitive mould" in aspect and Aktionsart, we must also acknowledge the reality of a category that encompasses both of these on a universal, conceptual level, i.e., that of aspectuality. From this perspective, to continue to insist on the semantic difference between aspect and Aktionsart proves problematic: on a more general level, both express the internal temporal structuring of a state of affairs, both are aspectuality, and this fact cannot, it seems, be simply banished to the diachronic level. Rather, it is the reason why - synchronically and diachronically - it is possible to assume this "commonality" in aspect and Aktionsart, and it is also the reason why it is possible for a diachronic shift of aspectual information between lexicon and grammar to take place. ${ }^{54}$ We can therefore repeat what has already been emphasised for aspectual verbal periphrases: it is only the means by which Aktionsart and aspect express this information that are different - lexicon or grammar - and these represent variable entities along a continuum.

\subsection{Verbal periphrases - a last interim conclusion}

In view of the quantity, variety and relevance of periphrastic constructions, which, in addition to inflectional past tense markings, express aspectual content especially in the Romance verbal system, it would seem difficult to refuse verbal periphrases an autonomous place of their own in this verbal system.

In the approach described here, the distinction between aspect and Aktionsart at the semantic level is overridden in a superordinate, conceptual universal content category, as is the distinction between so-called "aspectualgrammatical" and "actional verbal periphrases". The common denominator that connects all verbal periphrases is their semantics: all aspectual verbal periphrases express (together with other elements in the situation frame, of course) a particular realisation of a single content category, a particular combination of aspectual basic conceptualisations. The question, which is difficult to answer in the traditional semasiological view of aspectual categories, as to

54 For a different interpretation of the reasons for this shift, see Squartini (1998). 
which aspectual categories they can be assigned - whether they are aspect or Aktionsart - is simply no longer relevant: they are merely aspectuality.

I have shown that, contrary to one of the most serious objections to unidimensional models for the interpretation and description of aspectual information, the model developed here is able to describe and explain in detail the subtleties of the most varied phenomena that express aspectual information in states of affairs - especially the more complex phenomena, such as the verbal periphrases dealt with here as examples.

The possibilities of the model are not, however, limited to this. The particular advantages of this onomasiological treatment of verbal periphrases are, firstly, better comparability of formally different periphrases, for individual languages and crosslinguistically, and secondly, that these must no longer be represented as separate or hybrid linguistic means in the Romance verbal system, but as another equivalent possibility for the Romance language system to express aspectual contents. Through their integration into a general system of aspectuality based on cognitive principles, the verbal periphrases are thus finally treated as 'normal' forms in the Romance verbal paradigm and lose their special status as 'marked'. 